\title{
When the Guests Move In: Permanent Observers to the United Nations Gain the Right to Establish Permanent Missions in the United States
}

\begin{abstract}
M. A. Thomas $\dagger$
In 1987, Congress voted to close the Palestine Liberation Organization's observer mission at the United Nations. A U.S. district court refused to enforce the closure provision as it applied to the observer mission on grounds that the provision conflicted with the treaty defining the United States' obligations as host to the United Nations. This Comment examines the text and history of this treaty to ascertain whether the United States was obligated under international law to keep the PLO observer mission open. The author argues that the United States had no definite treaty obligation before Congress attempted to close the observer mission, but subsequently became obligated under international law by executive statements made during the congressional debates. The result is an undesirably broad international obligation created in violation of the Constitution.
\end{abstract}

The Red Queen broke the silence by saying to the White Queen, "I invite you to Alice's dinner party this afternoon."

The White Queen siniled feebly and said, "And I invite you."

"I didn't know I was to have a party at all," said Alice; "but, if there is to be one, I think I ought to invite the guests."

- Lewis Carroll ${ }^{1}$

\section{INTRODUCTION}

In 1987, Congress passed the Anti-Terrorism Act (ATA), ${ }^{2}$ which called for the closing of the U.S. offices of the Palestine Liberation Orgamization, including the PLO observer mission at the Umited

$\dagger$ B.A. 1985, University of California, Santa Cruz; J.D. Candidate, Boalt Hall School of Law, University of California, Berkeley. The author wishes to thank Professor David Caron, Naomi Roht-Arriaza, Margaret Lin, Steven Hardy, Wiltrud Harms, and the members and staff of the California Law Review for their assistance in preparing this Comment.

1. L. Carroll, Through the looking Glass, in The annotated alice 319-20 (Martin Gardner ed. 1960).

2. Pub. L. No. 100-204, $\$ \S 1001-1005,101$ Stat. 1406 (codified at 22 U.S.C.A. $\$ \S ~ 5201-5203$ (West 1990)) [hereinafter Anti-Terrorism Act or ATA]. 
Nations. ${ }^{3}$ A district court refused to enforce the Act's closure provision in United States v. Palestine Liberation Organization as it applied to the PLO mission at the United Nations. ${ }^{4}$ Relying in large part on statements made by members of the executive branch, the court found that the United States was obhgated by the Headquarters Agreement ${ }^{5}$ to refrain from closing the PLO's permanent observer nission.

The attempted closure of the nuission (and the later refusal to issue a visa to PLO Chairman Yasir Arafat to address the United Nations in New York) has raised serious questions concerning U.S. obligations to those invited to address or observe sessions of the United Nations General Assembly in New York. Must the United States allow permanent observers ${ }^{6}$ to estabhsh permanent missions in New York City? If so, does this obligation extend to nongovernmental organization (NGO) permanent observers? If the treaty does not impose such obligations, have they been created in another way? What steps can the United States legitimately take to safeguard its own security from the intrusion of undesirable invitees?

This Comment argues that, in order to prevent the closure of the PLO observer mission at the United Nations, the executive unilaterally reinterpreted and expanded U.S. obligations under the Headquarters Agreement. The United States had no obligation to permit permanent U.N. invitees to estabhsh permanent nissions outside the headquarters district before the executive niade statements to the contrary. By making statements of obligation, however, the executive bound the United States under international law. This expansion of U.S. treaty obligations was

3. The PLO observer mission was established in New York City pursuant to a 1974 invitation from the Umited Nations to the PLO to serve as a permanent observer, attending sessions of the General Assembly and speaking when recognized. G.A. Res. 3237, 29 U.N. GAOR Supp. (No. 31) at 4, U.N. Doc. A/9631 (1974).

4. 695 F. Supp. 1456 (S.D.N.Y. 1988).

5. The special obligations of the United States as the seat of the United Nations are set out in an agreement between the United Nations and the United States. Agreement Between the United Nations and the United States Regarding the Headquarters of the United Nations, June 26, 1947, United States-United Nations, 61 Stat. 756, T.I.A.S. No. 1676, 11 U.N.T.S. 11 [hereinafter Headquarters Agreement].

Although the Headquarters Agreement is a treaty under international law, it took the form of an executive agreement authorized by joint resolution of Congress. See S.J. Res. 144, 80th Cong., 1st Sess., 93 CoNG. REc. 10,515 (1947), and G.A. Res. 169, 2 U.N. GAOR at 91, U.N. Doc. A/519 (1947) [hereinafter Joint Resolution]. An executive agreement of this form is distinct from a treaty made with the advice and consent of the Senate under domestic law, but international law makes no distinction between the two. United States v. Palestine Liberation Org., 695 F. Supp. at 1458 n.2.

6. Permanent observers are those with permanent invitations to observe the General Assembly sessions. They can speak when recognized, but cannot vote. Guidelines for Implementation of General Assembly Resolutions Granting Observer Status on a Regular Basis to Certain Regional Intergovernmental Organizations, the Palestine Liberation Organization and the National Liberation Movements in Africa, 1975 U.N. JURID. Y.B. 164, 167, U.N. Doc. ST/LEG/ SER.C/13. 
unnecessary, unwise, and probably unconstitutional, as it overreached the congressional delegation of authority to conclude the Headquarters Agreement.

The decision of the district court in United States v. Palestine Liberation Organization ${ }^{7}$ compounded the effects of the executive action by upholding the executive interpretation of the Headquarters Agreement and striking down the provisions of the ATA that required closure of the observer mission. The court struck a regrettable new balance of power among the judiciary, executive, and Congress in the currently controversial area of treaty interpretation, effectively increasing the power of the executive and the judiciary at the expense of Congress.

The creation of a privilege of residence for U.N. mvitees may be troubling im and of itself, but even inore troubling is the precedent that it sets. In the face of mounting pressure to extend further privileges and inmunities to observing national liberation movements, the executive may avail itself again of this unconstitutional method of binding the United States, circumventing the congressional role in the imterest of political expediency. The further expansion of privileges and immunities for observing national hiberation movements-or for invitees generallyshould not be undertaken lightly.

Part I of this Comment outlines the possible sources of bilateral obligation under international law. Part II exammes the terms and preparatory works of the Headquarters Agreement, concluding that a limited right of residence was granted concomitant with the right of free transit. Part III explores the contemporaneous interpretations of the Headquarters Agreement, concluding that the Headquarters Agreement did not grant a permanent riglit of residence to permanent observers, and particularly not to NGO's. Part IV details the practice toward permanent observers, and finds that no custom-based obligation to permit permanent residence existed before the passage of the ATA. Part V examines the passage of the ATA and the executive staternents of obligation toward permanent observers, concluding tliat these stateinents were theinselves the source of a new obligation. Part V also exammes the United States v. Palestine Liberation Organization decision. Part VI addresses the policy concerns presented by the new residence obligations and by the process by which the United States acquired them. This Comment concludes witl a call to Congress to preserve U.S. rights with respect to invitees before the rights are further reduced. The executive should himit the new residence obligation to current permanent observer missions on the basis of past practice. The judiciary should limit United States v. Palestine Liberation Organization to its facts.

7. 695 F. Supp. 1456. 


\section{The Right of Residence: Possible Sources of INTERNATIONAL LEGAL OBLIGATION}

Arguments that the United States is obligated to extend permanent residence rights to permanent observers can be based on any of several international law doctrines; but any possible U.S. obligation to accord a right of residence to permanent observers must be found in express or implied U.S. consent to such an obhigation. ${ }^{8}$ Express consent is usually embodied in a written treaty. The International Court of Justice (ICJ), however, has found express consent in unilateral statenients of obligation. ${ }^{9}$ Implied consent, manifested by State practice and evidence of intent to be bound, niay act to modify a treaty or even to create a new independent bilateral obligation under the doctrine of "special custon1."10

\section{A. Treaty as a Source of Bilateral International Obligation}

The International Court of Justice hists treaty as a primary source of international legal obligation ${ }^{11}$ because a treaty is a clear expression of sovereign consent. ${ }^{12}$ International organizations, which have limited legal personality, ${ }^{13}$ can be parties to treaties. Such treaties constitute a binding source of international obligation for both the international organizations and the States that are parties to them. ${ }^{14}$ Hence, the Headquarters Agreement, which defines the special obligations of the United States as the seat of the United Nations, could have bound the United States to extend permanent resident rights to U.N. invitees. ${ }^{15}$

This Comment assunies that the purpose of treaty interpretation is to determine tlie original intent of the parties with respect to a given treaty term. ${ }^{16}$ To this end, it looks to the ordinary neaning of the treaty

8. See G. von Glahn, Law Among Nations $44-45$ (5th ed. 1981). Although nonconsensual sources of international law may exist, none has been advanced as the basis of a bilateral obligation. See M. JANIS, AN INTRODUCTION TO INTERNATIONAL LAW 46-54 (1988).

9. See M. JANIS, supra note 8, at 13-14; see infra notes 36-40 and accompanying text.

10. A. D'Amato, The Concept of Custom in INTERnational LAW 254-55 (1971).

11. Statute of the International Court of Justice, art. 38(1)(a), appended to U.N. CHARTER, 59 Stat. 1055, T.I.A.S. No. 993, 1970 U.N.Y.B. 1013 (1945) [hereinafter ICJ Statute].

12. M. JANIS, supra note 8 , at 10 .

13. The riglits and duties of the United Nations under international law are not necessarily the same as those of States. Reparation for Injuries Suffered in the Service of the United Nations, 1949 I.C.J. 174, 179.

14. See Vienna Convention on Treaties Concluded Between States and International Organizations or Between International Organizations, U.N. Doc. A/CONF.129/15 (Marcl 20, 1986).

15. See United States v. Palestine Liberation Org., 695 F. Supp. 1456 (liolding that permanent observers are entitled to maintain permanent offices in U.S. territory under the Headquarters Agreement).

16. A scliolar contemporary with the Headquarters Agreement wrote: 
term sought to be interpreted, the purpose of the treaty, the preparatory work of the treaty, the historical context of the treaty, further agreements between the parties on the same subject, subsequent practice by the parties tending to estabhish their original agreement, and all other relevant evidence. ${ }^{17}$

\section{B. Custom as a Source of International Obligation}

Custom is second only to treaty as a source of international law. ${ }^{18}$ A consistent practice can be a source of international law if it can be shown that the parties considered the practice to be pursuant to a legal obligation. ${ }^{19}$ When custom represents the practice of inany States, it serves as a generally accepted source of international law that binds the entire international community, ${ }^{20}$ soinetimes called "general custom." General custoin has two elements: consistent State practice, which may include acquiescence; and a sense of legal obligation or intent to be legally bound, sometimes called "opinio juris vel necessitatis," or simply, "opimo juris."21

Professor D'Amato's doctrime of special custom posits that a consistent practice among a smaller number of States can also create binding

The primary rule is that the tribunal should seek to ascertain from all the available evidence the intention of the parties in using the word or phrase being interpreted. The many rules and maxims which have crystallized out and abound in the text-books and elsewhere are merely prima facie guides to the intentions of the parties and must always give way to contrary evidence of the intention of the parties in a particular case.

A. MCNAiR, The LAW of Treaties 185 (1938) (footnotes omitted). "Intention" can be a very fluid term, referring to thc intent to adopt a particular mechanism of obligation, the purpose for assuming the obligation in the first place, or even the overarching reason for creating the treaty. This Comment assumes that State sovereignty requires the most restrictive sense of the word "intention": a State is only bound to do what the State specifically agreed to do.

17. I. Sinclair, The Vienna Convention on the Law of Treaties 115-17 (2d ed. 1984); Vienna Convention on the Law of Treaties, U.N. Doc. A/CONF.39/27, reprinted in U.N. Conference on the Law of Treaties, First and Second Sessions, Vienna 1969, Official Records, Documents of the Conference, at 287, U.N. Doc. A/CONF.39/11/Add.2, U.N. Sales No. E.70 V.5 (1971) [hereinafter VCLT]. Although the VCLT assigned weights to the differing types of evidence, establishing a hierarchy, the VCLT was concluded more than twenty years after the Headquarters Agreement. Because the VCLT cannot be applied retroactively, the hierarchy it establishes is not definitive in interpreting the Headquarters Agrecment. See id. arts. 31, 32 (rules of treaty interpretation); art. 4 (nonretroactivity of VCLT); see also U.N. CONFERENCE ON THE LAW OF Treaties, First SEsSion, VienNa 1968, Official Records, Summary Records of The Plenary Meetings and of the Meetings of the Committee of the Whole, U.N. Doc. A CONF.39/11, Sales No. E.68.V.7 (1969) [hereinafter U.N. CONFERENCE ON THE LAW OF TREATIES, VIENNA 1968, Summary Records].

18. ICJ Statute, supra note 11, art. 38(1). Custom is universally acknowledged as a source of international law binding the whole community of nations. M. JANIS, supra note 8 , at 36 .

19. See M. JANis, supra note 8 , at $35-43$.

20. See ICJ Statute, supra note 11, art. 38(1)(b); T. Elias, ThE MODERN LAW OF TREATIES 88 (1974).

21. M. JANIS, supra note 8, at 35-43; A. D'AMATo, supra note 10, at 7 . 
legal obligations as between those States. ${ }^{22}$ Under this theory, U.S. practice could give rise to a right of residence for permanent invitees if the practice created a special custoni between the United States and the United Nations. Although special custom is less well accepted than general custom as a source of international law,,$^{23}$ Professor D'Amato argues that the ICJ has explicitly recognized special custon 1 as a source of binding bilateral legal obligation. ${ }^{24}$

Professor D'Amato draws upon several cases to outline the elements of special custom. In the Asylum Case, ${ }^{25}$ which D'Amato describes as a special custom case, the court states that proof of custon1 requires "that the rule invoked . . . is in accordance with a constant and uniform usage practiced by the States in question, and that this usage is an expression of a riglit appertaining to the [invoking] State and a duty incumbent on [the other State]."26 In the Right of Passage Case, ${ }^{27}$ the ICJ found that Portugal had a right of way based on evidence of a local custoni continuously practiced in a constant and uniform inanner for over 125 years, and accepted as law by the parties. ${ }^{28}$ These cases indicate that a party proving special custom may have to n1ake a stronger showing of both consistent state practice and opinio juris than would a party proving general custon. ${ }^{29}$ Professor D'Amato cautions, however, that the exaniples are too few to spell out all the eleinents of special custom in international law. ${ }^{30}$ Because special custo1n is an unformed doctrine with linited acceptance, it may be a dubious basis for a U.S. obligation to the United Nations.

Instead of serving as a basis for a new obhgation, a consistent practice of the parties to a treaty, when coupled with a clear intent to effect a modification, could modify an existing treaty. ${ }^{31}$ Thus, rather than create a new legal obligation, United States practice could simply modify the

22. A. D'Amato, supra note 10, at 256. One of the clearest expositions of this obligation can be found in the Right of Passage Case (Port. v. India), 1960 I.C.J. 6, in which Portugal endeavored to show a right of passage over India to Portuguese enclaves:

[I] $t$ is objected on behalf of India that no local custom could be established between only two States. It is difficult to see why the number of States between which a local custom may be estabhished on the basis of long practice must necessarily be larger than two. The Court sees no reason why long continued practice between two States accepted by them as regulating their relations should not form the basis of mutual rights and obligations between the two States.

Id. at 39, quoted in A. D'AMATo, supra note 10, at 256.

23. A. D'AmAto, supra note 10 , at 263.

24. Id. at 252-57.

25. Asylum (Colom. v. Peru), 1950 I.C.J. 266, quoted in A. D'AmATo, supra note 10, at 253.

26. Id. at 276-77, quoted in A. D'AMATo, supra note 10, at 253.

27. (Port v. India) 1960 I.C.J. 6, quoted in A. D'AMATo, supra note 10, at 253.

28. Id., quoted in D'AMATo, supra note 10, at 253.

29. See A. D'AMATo, supra note 10, at 249.

30. Id. at 263.

31. I. SinCLAIR, supra note 17, at 138; M. JANIS, supra note 8, at 29. 
Headquarters Agreement. The doctrine that treaties can be modified by subsequent practice is, however, of questionable validity. The States that adopted the Vienna Convention on the Law of the Treaties ${ }^{32}$ overwlielmingly rejected a draft article that provided that a treaty could be modified by subsequent practice estabhishing the agreement of the parties to modify its provisions. ${ }^{33}$ The States rejected the article because they feared that under it low-ranking officials could bind a State to erroneous interpretations of treaty terins. ${ }^{34}$ To the extent that the Vienna Convention now constitutes customary international law, the theory that custom can modify a treaty is im doubt. ${ }^{35}$

Both the doctrine of special custoin and the doctrine of treaty modification require a heightened display of opinio juris. Thus, to find a custom-based obligation to perinanent observers there must be very clear evidence of U.S. intent to assume such an obligation. Furtlier, because neitler doctrine is universally accepted, the validity of international legal doctrine providing custom-based bilateral obligations is open to challenge.

\section{Unilateral Declarations as a Source of International Obligation}

Anotler possible source of imternational obligation based on express consent, besides written treaties, may be a unilateral declaration of obligation. ${ }^{36}$ The ICJ and its predecessor, the Pernnanent Court of International Justice, have held that statements made by higl-level government officials acting within the scope of their duties create binding obligations on the State.

In 1933, the Perinanent Court of International Justice held that the Norwegian Foreign Affairs Minister's oral declaration that "the Norwegian Government would not make any difficulty" witl respect to Danish claims on Greenland constituted a legally binding obligation on Norway. ${ }^{37}$ Similarly, the ICJ. found a French obligation to refrain from

32. VCLT, supra note 17.

33. Vienna Convention of the Law of Treaties, Draft Article 38, U.N. Conference on the Law of Treaties, Vienna 1968, Summary Records, at 208, U.N. Doc. AVCONF.39/11, U.N. Sales No. E.68 V.7 (1968). Draft Article 38 was rejected 54 to 15. M. JANIS, supra note 8, at 29.

34. M. JANis, supra note 8, at 29. See also I. SinclaIR, supra note 17, at 138 (expressing concern that a modification could be effected under the pretext of interpretation).

35. But see Report of the International Law Commission on the VCLT (Comment on Article 38), [1966] 2 Y.B. INT'L L. CoMM'N 169, 236, U.N. Doc. A/CN.4/SER.A/1966/Add.1; see also T. ElIAS, supra note 20.

36. See, e.g., Nuclear Tests (Austl. v. Fr.), 1974 I.C.J. 253, 267-70.

37. Legal Status of Eastern Greenland (Den. v. Nor.), 1933 P.C.I.J. (ser. A/B) 53, 69-71, quoted in M. JANIS, supra note 8, at 19 . The court continued:

The Court considers it beyond all dispute that a reply of this nature given by the Minister for Foreign Affairs on behalf of his Government in response to a request by the diplomatic representative of a foreign Power, in regard to a question falling within his province, is binding upon the country to which the Mimister belongs. 
above-ground nuclear testing based on unilateral statements made by members of the French Government. ${ }^{38}$ The court upheld the right of Austraha and all other interested States to rely on France's statements, even though French officials addressed the statements to third parties, such as the New Zealand Ministry of Foreign Affairs and the press. ${ }^{39}$ Thus, the United Nations and imterested member States may be entitled to rely on unilateral statements of obligation by U.S. government functionaries. ${ }^{40}$

In sum, the Headquarters Agreement is the most viable source of U.S. international legal obligation to provide permanent residence to perinanent observers. Alternately, the United States may be bound by custom that creates a special custom obligation or effects a treaty modification, although the viability of such obligations is open to question. Finally, the United States may be bound by unilateral statements of obhigation inade by U.S. government officials.

In the following Parts, I will explore each of these possible bases for a right of permanent residence.

II

\section{The Headquarters Agreement: Genesis of a Treaty- BASED OBLIGATION?}

Any examination of U.S. obligations to grant residence rights to perinanent observers must begin with the text of the Headquarters Agreement. The terms of the Headquarters Agreement are ambiguous, but they do not appear to grant residence rights to anyone. As discussed above, however, the principles of treaty interpretation allow reliance on secondary indicia of intent to niterpret an anbiguous treaty provision. An investigation of the preparatory works of the treaty shows that the parties intended linited residence rights for U.N. invitees.

Id., quoted in M. JANIS, supra note 8, at 19.

38. [N]ot all unilateral acts imply obligation; but a State may choose to take up a certain position in relation to a particular matter with the intention of being bound-the intention is to be ascertained by interpretation of the act. When States make statements by which their freedom of action is to be limited, a restrictive interpretation is called for. . . . One of the basic principles governing the creation and performance of legal obligations, whatever their source, is the principle of good faith. ... Thus interested States may take cognizance of unilateral declarations and place confidence in them, and are entitled to require that the obligation thus created be respected.

Nuclear Tests, (Austl. v. Fr.), 1974 I.C.J. 253, 267-70.

39. The statements need not be addressed to any particular State, and need not be accepted by any State, to be binding. Id. at 269.

40. Such a rule of international law inevitably increases the power of the executive branch of a State with a multi-branch government, and creates serious separation of powers problems. See infra notes 259-72 and accompanying text (discussing the constitutionality of the creation of such an international obligation solely by the executive branch). 


\section{A. The Terms of the Headquarters Agreement}

The Headquarters Agreement, which was concluded between the United States and the United Nations in 1947, sets out the umique obhigations of the United States as host State to the Umited Nations. ${ }^{41}$ Only two articles of the Headquarters Agreenient even mention residence. Article 5, entitled "Permanent Representatives of the United Nations," inentions resident representatives of the United Nations only incidentally. ${ }^{42}$ Article 4 of the Headquarters Agreenient, entitled "Communications and Transit," ${ }^{, 43}$ provides representatives with certain immunities from United States inımigration and residence laws. Article 4 provides in pertinent part:

\section{Section 11}

The federal, state or local authorities of the United States shall not inipose any impedinients to transit to or fron the headquarters district of (1) representatives of Menibers or officials of the United Nations, or of specialized agencies ..., (2) experts performing missions for the United Nations or for such specialized agencies, (3) representatives of the press ..., (4) representatives of non-governmental organizations recognized by the United Nations for the purpose of consultation under Article 71 of this Charter, or (5) other persons invited to the headquarters district by the United Nations or by such specialized agency on official business.

Section 13

(a) ....

(b) Laws and regulations in force in the United States regarding the residence of aliens shall not be applied in such nianner as to interfere with the privileges referred to in Section 11 and, specifically, shall not be applied in such a manner as to require any such person to leave the United States on account of any activities performed by him in his official capacity. In case of abuse of such privileges of residence by any such person in activities nil the United States outside of his official capacity, it is understood that the privileges referred to in Section 11 shall not be construed to grant him exemption from the laws and regulations of the United States regarding the continued residence of aliens provided that:

[certain specified procedures are followed]

(c) $\ldots$...

(d) Except as provided above in this section and in the General

41. Headquarters Agreement, supra note 5 .

42. Article 5 extends certain diplomatic privileges and immunities to principal permanent representatives of U.N. member States and specialized agencies, as well as "resident members of their staffs as may be agreed upon between the Secretary-General, the Government of the United States, and the Government of the Member concerned." Headquarters Agreement, supra note 5, art. 5 (emphasis added). The article specifies that privileges apply "whether [such persons are] residing inside or outside the headquarters district." Id. This article does not grant any rights of residence but clearly anticipates the possibility that permanent representatives might reside in the United States outside of the Headquarters District.

43. Id. art. 4. 
Convention, the United States retains full control and authority over the entry of persons or property into the territory of the United States and the conditions under which persons may remain or reside there.

(e) The Secretary-General shall, at the request of the appropriate American authorities, enter into discussions with such authorities with a view to making arrangements for registering the arrival and departure of persons which have been granted visas valid only for transit to and from the headquarters district and sojourn therein and its immediate vicinity.

(f) The United Nations shall, subject to the foregoing provisions of this section, have the exclusive right to authorize or prohibit entry of persons and property into the headquarters district and to prescribe the conditions under which persons may remain or reside there. ${ }^{44}$

Supporters of the permanent observer's right of year-round residence, and the court in United States v. Palestine Liberation Organization, cite sections 11 and 13 of article 4 as the source of that right. ${ }^{45}$ Yet, surprisingly, while section 13(f) expressly grants residence rights in the headquarters district itself, no section of the agreeinent provides for similar rights of residence outside the headquarters district. Thus, the very existence of such residence rights, the proper beneficiaries of such rights, and any further limitations on those rights inust be inferred froin the treaty terms and determined definitively by exainining other sources.

The exphicit grant of residence rights in the headquarters district might imply the absence of any grant of U.S. residence rights outside the district. Such an interpretation would be consistent with the longstanding canon of statutory construction that "expression of one thing excludes another." 46 Yet, logic dictates that the drafters intended to confer some right of U.S. residence. Otherwise, all representatives of ineinber States, the press, and specialized agencies, as well as all U.N. einployees and invitees, would be able to reside only in the headquarters district. If they did not reside there, they could be forced to leave the country at the end of one business day only to return the following morning. The first scenario, although originally anticipated, was ultimately abandoned. ${ }^{47}$ The second is patently ridiculous.

The treaty terms themselves also suggest that the United States and the United Nations conteinplated some right of U.S. residence. If the treaty confers only the right of safe passage to a fortress United Nations, the section 13(b) grant of iminunity from U.S. laws regarding the residence of aliens serves no purpose and the reference to "privileges of

44. Id. art. 4, $\S 11,13(\mathrm{~b})$-(f) (emphasis added).

45. U.N. and Arabs Protesting a Move by Congress to Shut P.L.O. Mission, N.Y. Times, Dec. 8, 1987, at 1; United States v. Palestine Liberation Org., 695 F. Supp. 1456, 1465-66 (S.D.N.Y. 1988).

46. "Expressio unius, exclusio alterius." H. Shapo, M. WALTER \& E. FAJANS, WRITING AND ANALYSIS IN THE LAW 59 (1989).

47. See infra text accompanying notes $72-77$. 
residence" is meaningless. ${ }^{48}$ Section $13(\mathrm{e})$ anticipates that the United States will give at least some persons visas valid for "sojourn [in the] immediate vicinity" of the headquarters district, although it falls short of asserting any right to sucl a visa.

Yet, the structure of sections 11 and 13 is puzzhing. Section 13(b) apparently grants no privileges beyond those granted in section 11 . Rather, section 13(b) limits privileges found in section 11. Section 13 refers to "privileges of residence," but section 11 appears to grant only a riglit of transit. Giving tlie term its plain meaning, "transit" cannot mean "continued residence." The section 11 term "transit" is therefore anıbiguous. Does a riglit of U.S. residence exist even tlougli not explicitly granted? If so, who has that right, and what, if any, are its limitations? To answer these questions, we nust determine tlie original intent of the parties to the Headquarters Agreement. Tlius, our focus must shift to other evidence, sucli as tlie preparatory works, the circumstances of the conclusion of the treaty, and the subsequent practice of the parties nnder the treaty.

\section{B. The Preparatory Work of the Headquarters Agreement}

It is not clear whether the Umited States and the United Nations contenuplated any right of residence in U.S. territory at the start of negotiations over the lieadquarters district. But the choice of a small urban site for the Umited Nations necessitated such rights. An examination of the preparatory works of the Headquarters Agreeinent and the U.S. domestic legislative history of the authorizing resolution of Congress show that the final agreenent contained a limited grant of U.S. residence riglits.

In 1946, the General Assembly authorized the U.N. SecretaryGeneral to begin negotiations with tlie United States toward an agreenuent defining the United States' unique obligations as host to the United Nations. ${ }^{49}$ Simultaneously, tlie U.N. Headquarters Comnission was searching for a permanent site for the organization's lieadquarters, whicl was entliusiastically dubbed by some "The World Capital."51 The two efforts were necessarily intertwined.

The Secretary-General based the negotiations on a preparatory draft

48. The section 13(b) statement that abusers of privileges of residence are subject to U.S. laws regarding the continued residence of aliens is unnecessary unless it applies to a class exempt from such laws.

49. 1946-47 U.N.Y.B. 104, U.N. Sales No. 1947 I.18.

50. Id. at 113 .

51. Report of the Headquarters Commission to the Second Part of the First Session of the General Assembly of the United Nations, 1 U.N. GAOR Supp. (No. 2) Annex 1 at 19, U.N. Doc. A/ 69 (1946) [hereinafter Headquarters Commission]. 
of an agreement written by the U.N. Sixth (Legal) Committee. ${ }^{52}$ The drafters envisioned a "seat" of the United Nations in the center of a larger U.N.-controlled "zone."53 The preparatory draft called for the Umited States to renounce jurisdiction "over any matter relating to entry into the zone and to the conditions under which persons may remain or reside there."54 The draft provided for a "right of unimpeded and safe transit through the territory of the United States of America to and from the zone" for, inter alia, representatives of member States and of NGO's in consultative status with the Economic and Social Council (ECOSOC). ${ }^{55}$ The preparatory draft further provided that "[i]mmigration and other regulations in force in the United States of America, regarding the entry and residence of foreigners, shall not be applied in such a manner as to interfere with" the right of safe transit. ${ }^{56}$ Further, while the Umited States could take necessary precautions to protect its own security, it could not interfere with the right of transit. ${ }^{57}$ No right of U.S. residence was exphicitly granted. The only other mention of residence is the article $\mathrm{V}$ provision extending diplomatic immumities to resident representatives and their staffs "whether residing inside or outside the zone." 58 Thus, although the draft appears to consider the possibility that U.N.-affiliated persons would live outside the zone in U.S. territory, nothing in the draft implies a grant of residence rights.

Although the United States had made few comments on the preparatory draft to avoid tipping its hand in negotiations, ${ }^{59}$ the parties' intent

52. 1946-47 U.N.Y.B. 104, U.N. Sales No. 1947 I.18. For the text of the preparatory draft, see 1(1) U.N. GAOR Annex 22 (Appendix II) at 650, U.N. Doc. A/43/REV.1, A/43/REV.1/ CORR.1, A/43/REV.1/CORR.2, and A/43/CORR.1 (appendix to summary of plenary meetings, Feb. 13, 1946) [hereinafter Preparatory Draft]. Article 4 of the preparatory draft, entitled "Communications and Transit to and from the Zone," provides in pertinent part:

Section 20. Representatives of Members, irrespective of the relations existing between their governinents and the Governinent of the United States of America, officials both of the United Nations and of the specialized agencies, and the families of these representatives and officials, shall at all times enjoy the right of umimpeded and safe transit through the territory of the United States of America to and from the zone.

Section 21. The accredited representatives of news agencies, whether press, radio, or films, and of non-governinental organizations recognized by the United Nations for the purpose of consultation, shall also enjoy the rights referred to in section 20 .

53. Preparatory Draft, supra note 52, arts. I, II.

54. Id. art. III, $\S 12$.

55. Id. art. IV, $\S \S 20-21$.

56. Id. art. IV, $\S 22$.

57. Id. art. IV, $\S 24$.

58. Id. art. $\mathrm{V}, \S 25$. This provision was left unchanged in the final draft. See supra note 42.

59. A working paper used by the delegation stated:

The United States would run a serious risk of committing itself to the draft in advance of negotiations if it took any part in the discussions. Any argument against unsatisfactory provisions might be held to imply acceptancc of provisions against which no objections were taken. No formal statement of reservations would be sufficient to dissipate this risk.

United States Delegation Working Paper (Feb. [7 or 8], 1946), [1946] 1 FOREIGN REL. U.S. 67, 70-71

(concerning the preparatory draft). 
can be inferred from subsequent negotiations. The United States negotiated with the Secretary-General from June 10, 1946 to June 19, 1946. The Secretary-General then issued a progress report that contained a working draft. ${ }^{60}$

The working draft differed from the preparatory draft in a number of ways. ${ }^{61}$ In the working draft, the United Nations relinquished control over the "zone," but retamed control of the seat, now called the "headquarters district."62 The Umited States specifically retained the right to control entry into and residence in U.S. territory, with the exception of the control it relinquished in the "Commumications and Transit" article and the General Convention on Privileges and Immumities. ${ }^{63}$ The Commumications and Transit article now stated that U.S. officials "shall

60. Joint Report by the Secretary-General and the Negotiating Committee on the Negotiations with the Authorities of the United States of America Concerning the Arrangements Required as a Result of the Establishment of the Seat of the United Nations in the United States of America, 1(2) U.N. GAOR C.6 Annex 25 at 408, U.N. Doc. A/67 [heremafter Working Draft Comments] and AV 67/Add.1 [hereinafter Working Draft] (1946).

61. Article 4 of the working draft, entitled "Communications and Transit," provides in pertinent part:

Section 21. The federal, state or local authorities of the United States of America shall not impose any impediments to transit to and from the headquarters district by representatives of Members or officials of the United Nations or their families or by experts performing missions for the United Nations. The appropriate United States authorities shall take such measures as may be necessary to protect such persons while in transit to or from the headquarters district against any violence and against any activities designed to interfere with such transit. This section does not apply to general interruptions of transportation, which are to be dealt with as provided in section 30 .

Section 22. Officials of specialized agencies which have been brought into relationship with the United Nations in accordance with the Charter and their families and representatives of the Press, or of radio, film or other information agencies who have been accredited by the United Nations in its discretion after consultation with the United States, and representatives of non-governmental organizations rccognized by the United Nations for the purpose of consultation under Article 71 of the Cliarter, shall hikewise enjoy the rights referred to in section $21 . .$.

Section 25. Laws and regulations in force in the United States of America regarding the entry aud residence of foreigners shall not be applied in such inanner as to interfere with the rights referred to in sections 21 and 22 . Visas required by the persons referred to in those sections shall be granted without charge and as promptly as possible.

Section 26. Except as provided in this article, and in the General Convention, the United States of America retains full control and authority over the entry of persons and property into the territory of the United States and the conditions under which persons may remain or reside there.

The Seeretary-General shall, at the request of the appropriate United States authorities, enter into discussions with such authorities, with a view to making arrangements for registering the arrival and departure of persons who have been granted visas valid only for transit to and from the zone and sojourn therein and its immediate vicinity.

Working Draft, supra note 60. In the working draft, the United Nations retained control of the seat, now called the "headquarters district," but relinquished control over the larger zones. Id. arts. I and III. It is in this draft that sojourning in the immediate vicinity of the United Nations is first mentioned. Id. art. IV, $\$ 26$.

62. Id. art. II, $\S 2$, art. III, $\S \S 11-12$.

63. Id. art. IV, $\S 26$. Article IV in all three drafts is the Communications and Transit article. See supra notes $43 \& 52$. 
not impose any impediments to transit to and from the headquarters district,"64 and that the "[1]aws and regulations in force in the United States of America regarding the entry and residence of foreigners shall not be applied in such manner as to interfere" with the transit right. ${ }^{65}$

But, like the preparatory draft, the working draft contained no explicit grant of residence rights in U.S. territory, despite its acknowledgement that such residence might take place. Comments made by the Secretary-General are at best ambignous as to whether the working draft granted residence rights. The Secretary-General wrote that resident delegations of member States would be a "special situation,"66 rather than the norm. Further, he noted that "[i]t has been agreed that the United Nations . . . may invite specialized agencies which have been brought into relationship with it to establish their headquarters in the zone, or even in the district." 67 The existence of a separate agreement may indicate that U.N.-affiliated persons had no general right of residence in the zone or in U.S. territory. In addition, the Secretary-General remarked that, despite changes of wordimg in the sections dealing with the rights of persons having occasion to come to the headquarters district, the working draft extended no rights to such persons above those extended to them in the preparatory draft. ${ }^{68}$

The failure of the working draft to provide U.S. residence rights is not surprising given the parties' expansive plans for the headquarters district. Contemporaneous with these negotiations, the Headquarters Cominission was drafting plans for a Umited Nations headquarters the size of a small city. Because the Commission contemplated a site large enough to house all U.N.-related personnel and offices within the headquarters district, residence rights outside the district would have seemed unnecessary.

In October of 1946, the Headquarters Commission submitted a report to the General Assembly evaluating the merits of a number of proposed sites and estimating the size of the required facilities. ${ }^{69}$ Although the Commission identified three possibilities-in which all, some, or no U.N.-affiliated personnel lived on the site-it assumed that the entire community would reside in the headquarters district itself. $^{70}$ Land use estimates were calculated to include residences, apartinents, playgrounds, hotels, shops, parks, businesses, and offices. ${ }^{71}$

64. Id. art. IV, § 21 .

65. Id. art. IV, $\S 25$.

66. Working Draft Comments, supra note 60, at 413 (comments on art. v).

67. Id. at 411 (comments on art. II).

68. Id. at 413 (comments on art. IV).

69. See Headquarters Commission, supra note 51, Annex 21 at 122.

70. Id. Annex 1 at $15 \&$ Annex 21 at 122.

71. Id. Annex 6 at 65. 
On December 14, 1946, the General Assembly authorized the Secretary-General to conclude the Agreement on the basis of the working draft. ${ }^{72}$ On the same day, however, the General Assembly accepted John D. Rockefeller, Jr.'s gift of money for the purchase of a small parcel of land im New York City as the site for the permanent headquarters. ${ }^{73}$ The parcel was approximately 17 acres; $^{74}$ in contrast, Headquarters Commission estimates called for 2,240 acres for office buildings alone, and an additional 7,000 to 11,000 acres to house the U.N. commumity. ${ }^{75}$

The selection of the small urban site required a change in fundamental premises and a renegotiation of provisions of the Headquarters Agreement. $^{76}$ Persons affiliated with the Umited Nations would now need to hive outside the headquarters district. This change meant that the Headquarters Agreement had to be modified to give U.N.-affiliated persons some right of residence $\mathrm{m}$ the United States, but U.S. concern over the security imphications of such a grant led to a delay $m$ negotiations. ${ }^{77}$

During the protracted negotiations for a final agreement, the negotiators discussed residence rights in the United States. ${ }^{78}$ Testifymg im congressional hearings on the Headquarters Agreement, Mr. Fahy, the Legal

72. 1947-48 U.N.Y.B. 197, U.N. Sales No. 1949 I.13.

73. Id. at 222.

74. 1 The United STATES AND the UNITED Nations: Report by the U.S. PResident to Congress 25 (1947). The headquarters district is in the borough of Manhattan in New York City. The original grant was bounded to the north by East 48th Street, to the east by Franklin D. Roosevelt Drive, to the south by East 42nd Street, and to the west by First Avenue. Headquarters Agreement, supra note 5, Annex 1, 61 Stat. 3416, T.I.A.S. No. 1676, 12 Bevans 956. As the United Nations required additional space, additional treaties were concluded expanding the headquarters district to include 805-7 First Avenue, 343 East 45th Street, the 3rd and 6th floors of 866 U.N. Plaza, the 2nd floor of 666 3rd Avenue, and the 22nd and 23rd floors of 485 Lexington Avenue. Supplemental Agreement Regarding the Headquarters of the United Nations, February 9, 1966, United States-Umited Nations, 17(2) U.S.T. 2319, T.I.A.S. No. 6176; Second Supplemental Agreement Regarding the Headquarters of the United Nations, August 28, 1969, United StatesUnited Nations, 20(3) U.S.T. 2810, T.I.A.S. No. 6750.

75. Headquarters Commission, supra note 51, Annex 6 at 65 . There are 640 acres in a square mile.

76. 1947-48 U.N.Y.B. 197, U.N. Sales No. 1949 I.13.

77. Reporting on the renegotiation, the U.N. Secretary-General wrote that " $[t]$ he conclusion of the Agreement was somewhat delayed, however, owing to a difference of opinion as regards the extent of the privilege of residence in the United States of America. After protracted negotiations, a compromise text was finally adopted." Agreement Between the United Nations and the United States of America Regarding the Headquarters of the United Nations, Report by the Secretary-General, 2(3) U.N. GAOR C.6 Annex 11 at 328, U.N. Doc. A/371 (1947) [hereinafter Final Report]. See also Hearings on S.J. Res. 144 Before the Senate Comm. on Foreign Affairs, 80th Cong., 1st Sess. 37 (July 8, 1947) (statement of Mr. Fahy that negotiation of transit and residence right had been difficult because of U.S. insistence on limitation) [hereinafter Senate Foreign Relations Comm., July 8].

78. Senate Foreign Relations Committee, July 8, supra note 77, at 37. A State Department memorandum regarding the negotiations also referred to difficulties over the power to withdraw "the privileges of staying in the country." Memorandum by the Legal Adviser (Fahy) to the United States Representative at the United Nations (Austin) (April 23, 1947), [1947] 1 FoREIGN REL. U.S. 24, 25 n.9 [hereinafter Memorandum by the Legal Adviser (Fahy)]. 
Adviser to the State Department, stated that the agreement gave a right of U.S. residence in the immediate vicimity of the headquarters district. ${ }^{79}$ He testified that "[i]t is not contemplated that the blocks in the city where the headquarters will be, will afford residential facilities for all who come or are attached to the United Nations." 80

Changes in the final Headquarters Agreement reflect this grant of residence rights. Section 13(b) was added, mentioning for the first time "privileges of residence" and the application of U.S. laws to those who abuse such privileges. ${ }^{81}$ U.S. control over entry into and residence in U.S. territory was now limited, not by the entire Communications and Transit article, but specifically by the new section $13 .{ }^{82}$ Section 13 (b) thus grants some right of residence, despite its lack of explicit language.

The text of the joint resolution of Congress that authorized the Headquarters Agreement also evidences a grant of residence rights. The so-called section 6 security reservation states that "[n]othing in the Agreeinent shall be construed as im any way ... weakening the right of the Uinited States to . . completely control the entrance of aliens into any territory of the Umited States other than the lieadquarters district and its immediate vicinity." 83 The iniplied surrender of control over entrance into the immediate vicinity of the headquarters district would be necessary only if U.N.-affiliated persons had some right to reside there.

Thus, a close examination of the evolution of the articles of the Headquarters Agreement reveals that, althougl early drafts did not appear to grant any riglit of U.S. residence, the parties to the Agreement defimitely intended that it grant some residence rights to U.N.-affiliated persons. The omission from the final Headquarters Agreement of an express right of residence in U.S. territory surrounding U.N. Headquarters may be explainable as careless draftsmanship in updating a previous draft that did not purport to grant such a right. Section 13 creates a "privilege" of residence by exempting residence incidental to section 11

79. Hearings on S.J. Res. 144 Before Subcomm. No.6 of the House Comm. on Foreign Affairs, 80th Cong., 1st Sess. (July 29, 1947), reprinted in 1 Problems of World WAR II AND ITS AFtermath: SELECTEd EXecutive Session HeARINGS OF THE CoMmitTEe, 1943-1950, at 247, 249 (1976) [hereinafter House Comm. on Foreign Affairs]; Hearings on S.J. Res. 144 Before the Senate Comm. on Foreign Affairs, 80th Cong., 1st Sess. 60 (July 12, 1947) (statement of Mr. Fahy that those inentioned in section 11 are subject to U.S. law "except as they are permitted to come to the Headquarters and its environments for purposes of domicile.") [lereinafter Senate Foreign Relations Comm., July 12]; see also Senate Foreign Relations Comm., July 8, supra note 77, at 30-39 (discussion of limited residence right).

80. House Comm. on Foreign Affairs, supra note 79, at 249.

81. Headquarters Agreeinent, supra note 5, art. IV, § 13(b)-(c). This section is quoted at supra text aceoinpanying note 44 .

82. Id. art. IV, § 13(d).

83. Joint Resolution, supra note $5, \S 6$. 
transit from the normal operation of U.S. law. This privilege extends to all persons enumerated in section 11, including representatives of NGO's in consultative status with ECOSOC, and invitees.

The Secretary-General of the United Nations and a representative of the Department of State signed the final Headquarters Agreenient on June 26, $1947 .{ }^{84}$ It was approved by a jomt resolution of Congress on July 6, 1947, and signed into law by President Truman that August. ${ }^{85}$ The General Assenibly approved the Agreenient on October 31, $1947 .^{86}$

Although the preparatory works and historical context of the Headquarters Agreenient show that a privilege of residence was granted, they do not define that privilege adequately. Some limitations on the right are apparent. Section 11 limits the recipients of that right, while section 13(b) conditions the right on nonabuse of privilege. Section 13(e) appears to confine U.N.-affiliated residence to "the immediate vicinity" of the headquarters district. The following Part seeks a better definition of the granted residence rights using conteniporaneous interpretations of the Headquarters Agreement.

\section{III}

\section{LIMITATIONS ON THE RIGHT OF U.S. RESIDENCE: CONTEMPORANEOUS INTERPRETATIONS OF THE HEADQUARTERS AGREEMENT}

An examination of the earliest interpretations of the Headquarters Agreement denionstrates that the Headquarters Agreement granted only very hinited U.S. residence rights. Neither the United States nor the United Nations contemplated the extension of permanent residence rights to mvitees, nor did they anticipate that NGO's might one day be nivited as permanent observers. The linitations iniphed by the term "abuse of privilege" in section 13(b) and the scope of the section 6 security reservation are less clear.

\section{A. Geographic Limitations on Residence Rights}

The text of the Headquarters Agreement does not unanibiguously linit the residence rights of invitees to within the headquarters district or its immediate vicinity. ${ }^{87}$ It is clear, however, fron 1 contemporaneous statements $\mathrm{m}$ congressional hearings that invitees are entitled to reside only in the immediate vicinity of the headquarters district. ${ }^{88}$ Although

84. 1947-48 U.N.Y.B. 197, U.N. Sales No. 1949 I.13.

85. Id.

86. Id. at 199.

87. Headquarters Agreement, supra note 5, § 13(e).

88. See, e.g., Memorandum by the Assistant Secretary of State for United Nations Affairs (Hickerson) to the Secretary of State (Feb. 6, 1952), [1952-54] 3 FoREIGN REL. U.S. 198, 198 
the term "immediate vicinity" was never defined by subsequent treaty, ${ }^{89}$ it has been interpreted to limit invitees to within a twenty-five-mile radius of the headquarters district. 90

\section{B. Duration of Residence Rights in the United States}

Early interpretation and practice under the Headquarters Agreement demonstrate that the agreeinent conferred only temporary residence rights. The agreement did not confer a right of permanent U.S. residence even on representatives of U.N. member States, because the need for member States to establish permanent missions was not immediately apparent. States attending sessions of the League of Nations, the forerunner organization of the United Nations, had sent delegations rather than establish permanent missions. ${ }^{91}$ Thus, the U.N. Charter, the constitutions of the Specialized Agencies, and tlie General Convention on the Privileges and Immunities of the Umited Nations provide only for delegations to the United Nations, not for permanent missions. ${ }^{92}$ At most, the U.N. Charter envisaged permanent members of the Security Council as permanent representatives. ${ }^{93}$

In November 1948, the representative of Bolivia, concerned that "permanent delegations to the United Nations had been set up without . . . any legal basis, their existence being justified solely by practical considerations," tions of States to establisli permanent nrissions. ${ }^{95}$ The United States "wlioleheartedly approved the initiative taken by the Bolivian delegation,"96 even though the Assistant Secretary-General of the United

(concluding that the United States could restrict U.N. aliens to the headquarters district and its immediate vicinity); The Secretary of State to the Attorney-General of the United States (Clark) (March 8, 1949), [1949] 2 ForeIGN REL. U.S. 58, 59 (invitees allowed to sojourn in immediate vicinity of headquarters district); see also House Comm. on Foreign Affairs, supra note 79, at 249 (statement of Mr. Fahy that U.S. access is limited to the immediate vicinity of the headquarters district). But see Memorandum by the Assistant Secretary of State for United Nations Affairs (Hickerson). (June 9, 1950), [1950] 2 FORE1GN REL. U.S. 54, 55 (arguing that the United Nations might relocate if the United States so limited residence rights).

89. Originally, "immediate vicinity" was to be defined in a supplementary agreement. Joint Resolution, supra note $5, \S 6$.

90. 1976 Dig. U.S. PRAC. INT'L L. 74.

91. 3(1) U.N. GAOR C.6 (124th mtg.) at 619 (1948) (remarks of Mr. Anze Matienzo).

92. L. Dembinski, The Modern LaW of Diplomacy 49, 75 (1988).

93. 3(1) U.N. GAOR C.6 (124th mtg.) at 621 (1948) (remarks of Mr. Kerno, Assistant Secretary-General of the United Nations); see also Senate Foreign Relations Comm., July 8, supra note 77, at 36 (statement of Mr. Fahy). This is because the General Assembly usually meets for no more than three months of the year. Rules of Procedure of the General Assembly, U.N. Doc. A/520/ Rev.15, at 1 \& Annex V, para. 4, at 50 (1985). The Security Council has only five permanent members including the United States. U.N. CHARTER art. 23, para. 1.

94. 3(1) U.N. GAOR C.6 (124th mtg.) at 619 (1948) (remarks of Mr. Matienzo).

95. 3(1) U.N. GAOR Annex (Agenda Item 47) at 59-60, U.N. Doc. A/609 (1948).

96. 3(1) U.N. GAOR C.6 (124th mtg.) at 628 (1948) (remarks of Mr. Maktos). 
Nations pointed out that "[a]s the General Assembly met for only part of the year, it could not have permanent representatives."97 The Bolivian proposal passed as General Assembly resolution 257(III). ${ }^{98}$. The resolution did not mention permanent observers or invitees.

Thus, the U.S. consent to the establishment of permanent missions of U.N. member States did not derive from the Headquarters Agreement, but from U.S. support for the subsequent resolution sponsored by Bolivia. The Headquarters Agreement confers no permanent residence rights on anyone. Because observer missions and invitees were not included in the Bohivian resolution, any grant of permanent U.S. residence rights to permanent observers must be found elsewhere.

Early documents confirm that the United States intended invitees to have only temporary residence rights. The Headquarters Agreeinent limited the visits of invitees to the period necessary to conduct their "official business." 99 The United States, which defined "official business" very narrowly, ${ }^{100}$ interpreted the section $11(5)$ invitee classification as applying only to "extraordinary" consultations with the United Nations. ${ }^{101}$ According to reinarks made during an executive session meeting of the Senate Foreign Relations Committee, the State Department did not anticipate granting visas for a period longer than six inonths. ${ }^{102}$

Thus, neither the United States nor the United Nations contemplated permanent U.S. residence as of right for either State missions or invitees at the time the Headquarters Agreement was concluded.

97. 3(1) U.N. GAOR C.6 (124th mtg.) at 621 (1948) (remarks of Mr. Kerno).

98. L. DEMBINSKI, supra note 92, at 75 .

99. Headquarters Agreement, supra note 5, art. IV, § 11(5).

100. See 1951 U.N.Y.B. 593, U.N. Sales No. 1952 I.30; see also The Secretary of State to the Ambassador in Denmark (Anderson) (Oct. 25, 1950), [1950] 2 ForeIGN REL. U.S. 56, 59 (at the time the Headquarters Agreement was concluded, it was envisaged that members of the press would be resident only for short periods of time).

101. See Memorandum by the Legal Adviser (Fisher) to the Assistant Secretary of State for United Nations Affairs (Hickerson) (Sept. 26, 1950), [1950] 2 FOREIGN REL. U.S. 65, 68 [hereinafter Memorandum by the Legal Adviser (Fisher)]. The U.N. Secretary-General had to certify the official , business of the invited individual. See Minutes of the Eighth Meeting of the United States Delegation to the General Assembly, New York (Sept. 27, 1950), [1950] 2 ForeIGN REL. U.S. 72, 73 [hereinafter Minutes]. The certification may last only until the session or invitation expires. The Deputy Attorney-General of the United States (Malone) to the Deputy Legal Adviser of the Department of State (Tate) (Dec. 23, 1952), [1952-54] 3 ForeIGN REL. U.S. 233, 233 [hereinafter Deputy AttorneyGeneral of the United States (Malone)] (invitee only allowed to participate in the present session of the General Assembly).

102. Senate Foreign Relations Comm., July 12, supra note 79, at 103 ("Mr. Fahy: .. The holder [of the visa] merely has something in his pocket that restricts him to six months in this country. ... Senator Hatch: If he stays over six months he is in the same shape as the fellow who goes outside the headquarters district."). 


\section{Restrictions on Residence Rights for NGO's}

The early practice of the United States toward NGO's affiliated with the United Nations shows that, given the U.S. vision of the proper role of NGO's, it was very unlikely that the United States would have been amenable to affording them permanent residence rights. The United States initially imsisted that NGO's could be invited only to consult with ECOSOC (the Economic and Social Council) under article 4, section 11(4). They conld not be invited as section 11(5) invitees. Invitees were to be individuals with "official business" $\mathrm{m}$ extraordinary consultation at the United Nations.

Article 71 of the U.N. Charter provides that ECOSOC can arrange to consult with NGO's concerning matters within their competence. ${ }^{103}$ Because Article 71 sets out an explicit role for NGO's, the United States initially rejected any other role. In 1946, even before the Headquarters Agreement was concluded, the question arose whether the World Federation of Trade Uinons could sit in the General Assembly and participate and vote in General Assembly sessions. ${ }^{104}$ The United States objected to this new role for NGO's. The U.S. delegation to the United Nations stated in a position paper that "[t] Article 71 for a special type of relations between the ECOSOC and private nongovernmental organizations. By iniplication the Charter does not contemplate any similar relations directly with the General Assembly." 105 Accordingly, the United States interpreted section 11(4) to permit transit rights for NGO's only when they request entry for the purpose of consulting with ECOSOC or its subsidiary bodies. ${ }^{106}$

In 1951, the United States and the United Nations concluded negotiations concerning the admission of NGO representatives. ${ }^{107}$ The United States argued that, although it was obligated to permit such transit when the consultant had official business, neither the Headquarters Agreement nor the U.N. Charter allowed NGO's to attend all General Assembly neetings simply because the meetings were of general educational interest. ${ }^{108}$ To resolve the conflict, the General Assembly passed a resolution that allowed the Secretary-General to invite consul-

103. U.N. ChARTER art. 71.

104. See United States Delegation Position Paper (Jan. 21, 1946), [1946] 1 FoREIGN REL. U.S. 503, 503.

105. Id. at 504.

106. Memorandum by the Legal Adviser (Fisher), supra note 101, at 66; see also Telegram from the Secretary of State to Ambassador in India (Henderson) (Sept. 8, 1950), [1950] 2 FoREIGN REL. U.S. 63, 64 ("Dept holds Sec 11(4) Hdqrs Agreement obligates U.S. facilitate attendance nongovernmental org reps only at mtgs ECOSOC and subsidiary bodies and not repeat not GA [General Assembly] or other organs.").

107. 1951 U.N.Y.B. 593, 593-94, U.N. Sales No. 1952 I.30.

108. Id. 
tants to the General Assembly "whenever economic and social matters are discussed which are within the competence of the [Economic and Social] Council and of the organization concerned."109

In 1952, the United States reaffirmed its view of the narrow role of NGO's by denying a visa to a controversial NGO representative. To avoid an outcry, however, it permitted the representative to be admitted for a General Assembly session under section 11(5) as an invitee on official business, not as an NGO representative under section 11(4). ${ }^{110}$ The representative, a former Communist Party member, was otherwise inadmissible to the United States. ${ }^{111}$

Consistent with the early practice under the Headquarters Agreeinent, the NGO was not invited as an organization under section 11(5); the individual representative was invited and his official business was certified by the U.N. Secretary-General. ${ }^{112}$ In the U.S. view, section 11(5) was to be used for one-time consultations. ${ }^{113}$ Nor did the United States anticipate that the Secretary-General would have the legal authority to confer invitee status on anyone he pleased. ${ }^{114}$ Thus, early U.S. understandings of the role of NGO's, of the definition of "official business," and of the proper use of the invitee classification show that the United States would not have granted permanent residence rights to NGO's.

\section{Loss of Rights for Abuse of Privilege}

Section $13(\mathrm{~b})$ provides residence rights on the condition that the beneficiary not "abuse" the privilege; abuse of privilege subjects the beneficiary to U.S. laws on the contimued residence of aliens. ${ }^{115}$ The Umited

109. Id. at 597.

110. The Secretary of State to the Embassy in South Africa (Oct. 31, 1952), [1952-54] 3 FORE1GN. REL. U.S. 229, 230.

111. Deputy Attomey-General of the United States (Malone), supra note 101, at 233.

112. See Secretary of State to the Embassy in South Africa, supra note 110, at 230 (stating that an NGO had designated its representative, and the representative had the status of a section 11(5) invitee); see also Minutes, supra note 101, at 73 (expressing a desire for a broader definition of official business than certification by the Secretary-General that the invitee had been requested by the Assembly).

113. "Section 11(4) is to provide for ordinary, rather than the extraordinary, consultation of representatives of non-governmental organizations . . ." Memorandum by the Legal Adviser (Fisher), supra note 101, at 68.

114. Senate Foreign Relations Comm., July 12, supra note 79, at 63 ("Chairman [Vandenberg]: ... But what I want to know is, can the Secretary-General issue a visitor's permit to anybody he pleases who wants to come here? Mr. Fahy: No, sir. Senator George: No, I do not think that. It is not contemplated."). Nor, it seems, did the United States anticipate that the United Nations would have the effective authority to invite unwelcome visitors. See Memorandum by the United States Representative at the United Nations (Lodge) (May 19, 1953), [1952-54] 3 FORE1GN REL. U. S. 278, 280 (U.S. representative to United Nations relying on U.S. vote and prestige to control the issuance of invitations).

115. Headquarters Agreement, supra note 5, art. IV, $\S 13(b)$. This section is quoted at supra text accompanying note 44 . 
Nations has conceded the U.S. right to deport in case of abuse. ${ }^{116}$ The parties, however, have not defined the term "abuse."

The initial U.S. interpretation was that engaging in any activity other than official functions was abuse of privilege, regardless of whether that activity violated U.S. law or constituted grounds for deportation. ${ }^{117}$ There is substantial evidence, however, that this interpretation was unwarranted. A State Departinent meino examining the evidence concluded that to be abuse an activity must at least constitute a basis for deportation, if not violate a U.S. law. ${ }^{118}$ Moreover, the United Nations had rejected a draft version of section 13 that exphicitly gave the United States the right to deport for any unofficial activity. ${ }^{19}$ The section 13 scheme allowing deportation for abuse and providing for procedural safeguards had been a coinpromise position. ${ }^{120}$

Thus, although there is no clear agreement on the meaning of abuse, it is possible that residence rights may be terminated when an invitee violates U.S. law or gives grounds for deportation.

\section{E. The Section 6 Security Reservation}

In its joint resolution authorizing the President to sign the Headquarters Agreement, Congress included the section 6 security reservation, which provides:

Section 6. Nothing in the agreement shall be construed as in any way diminishing, abridging, or weakening the right of the United States to safeguard its own security and completely to control the entrance of aliens into any territory of the United States other than the headquarters district and its immediate vicinity, as to be defined and fixed in a suppleinentary agreement between the Government of the United States and the United Nations in pursuance of section 13(3)(e) of the agreement, and such areas as it is reasonably necessary to traverse in transit between the same and foreign countries. ${ }^{121}$

Although some meinbers of Congress have invoked the section 6 reservation as grounds for closure of the PLO permanent observer inis-

116. See The Secretary-General of the United Nations (Hammarskjold) to the United States Representatives at the United Nations (Lodge) (June 22, 1953), [1952-54] 3 FoRE1GN REL. U.S. 293.

117. Memorandum by the Chief of the Division of International Administration (Ingram) to the Assistant Secretary of State for United Nations Affairs (Hickerson) (Oct. 31, 1951), [1951] 2 FOREIGN REL. U.S. 72, 72-73 (Visa Division interpreted abuse as engaging in any activity outside official function); The Deputy Attorney-General of the United States (Malone), supra note 101, at 234 (terms of admission of iuvitee preclude him from any non-official activities); The Secretary of State to the Ambassador in Denmark (Anderson), supra note 100, at 58-59 (correspondent abused his residence privileges by engaging in activities outside his official duties).

118. Memorandum Prepared in the Department of State, (Nov. 2, 1951), [1951] 2 FORE1GN REL. U.S. $73,74$.

119. Memorandum by the Legal Adviser (Fahy), supra note 78, at 25 n.9.

120. See Final Report, supra note 77, at 328.

121. Joint Resolution, supra note 5 (emphasis added). 
sion, ${ }^{122}$ the reservation's effect on U.S. obligations under the Headquarters Agreement is unclear.

The Headquarters Agreement was brought into effect by an exchange of notes on November 21, 1947. The U.S. note stated that the United States was prepared to apply the Headquarters Agreement "subject to" the provisions of the autliorizing joint resolution of Congress. ${ }^{123}$ The General Assembly was aware of the section 6 reservation, published it in General Asseinbly records, and debated it in the Sixth (Legal) Committee. ${ }^{124}$ Nevertheless, when the Umited States refused to grant visas to two NGO representatives, citing the security reservation, the Secretariat issued a memorandum denying that the General Assembly lad ever received notice that the United States intended the resolution to constitute a reservation to the Headquarters Agreement. The Secretariat also demed that the General Assembly had ever accepted it as such. ${ }^{125}$

The Secretariat's argument is weak. The General Assembly had exphicit notice that the Headquarters Agreement would be "subject to" the provisions of the joint resolution. The United Nations' exchange of notes with the United States and forty years of performance under the Headquarters Agreement evidences its acceptance of the reservation. ${ }^{126}$

More problennatic, however, is whether the section 6 security reservation limits U.S. obligations to permit transit and residence under article 4, sections 11 and 13 of the Headquarters Agreement. The initial sentence of the reservation retaims for the United States the right first "to safeguard its own security," and second "to control the entrance of aliens into any territory of the United States other than the headquarters district and its immediate vicinity." 127 The second clause indicates that the United States surrenders control over the entry of aliens into the headquarters district and its immediate vicinity. But it is not clear whether the Umited States retains the riglit to safeguard its own security under the first clause if to do so would involve exercising control over the entry of aliens into the headquarters district and its immediate vicinity. The

122. 133 Cong. REC. S6449 (daily ed. May 14, 1987) (remarks of Senator Dole); 133 CoNG. REC. S13,852 (daily ed. Oct. 8, 1987) (remarks of Senator Grassley).

123. Memorandum by the Assistant Secretary of State for United Nations Affairs (Hickerson) to the Secretary of State, supra note 88, at 201.

124. Memorandum Prepared in the Office of the Assistant Legal Adviser for United Nations Affairs (Meeker): Part I (April 15, 1953), [1952-54] 3 FOREIGN REL. U.S. 262, 263 [hereinafter Meeker Memo].

125. 15 U.N. ESCOR Annex (Agenda Item 34) at 2, U.N. Doc. No. E/2397 (1953), quoted in Meeker Memo, supra note 124, at 262.

126. See Meeker Memo, supra note 124, at 264-65. The alternative would be to believe that the United Nations rejected the reservation, which under international law would result in the negation of the entire Headquarters Agreement. See M. JAN1S, supra note 8, at 20 (rejection of a reservation to a bilateral agreement prevents the formation of any binding agrecment).

127. Joiut Resolution, supra note $5, \S 6$. 
United States has consistently maintamed, on the basis of the legislative history of the joint resolution, that the second clause does not limit the first. ${ }^{128}$ Accordingly, the Umited States claims the right to do whatever is necessary to safeguard U.S. security.

The legislative history of the reservation supports this U.S. contention. ${ }^{129}$ The initial Senate draft of the reservation atteinpted only to address grave concerns about the security threat that would be posed by U.N.-affiliated persons if they had the right of free travel. Accordingly, it contained only the second clause retaining control over entry except in the inimediate vicimity of the headquarters district. ${ }^{130}$ But when the House received the draft of the Senate resolution, it was concerned about the surrender of control of entry to the headquarters district and its immediate vicinity. The House amended the resolution by adding the first clause, giving the United States the right to safeguard its own security, and limitimg the surrender of control in the second clause. ${ }^{131}$ Therefore, the official U.S. position is that the Umited States may curtail transit to and residence in the headquarters district and its imınediate vicinity when necessary to safeguard U.S. security. ${ }^{132}$

128. See infra note 132 and accompanying text.

129. See Meeker Memo, supra note 124, at 266. For readers wishing to delve further into the legislative history of the authorizing resolution, Mr. Ives and Mr. Warner introduced Senate Joint Resolution 144 on July 3, 1947. Subcommittee No. 6 of the House Committee on Foreign Affairs considered it on July $9,14,18,19$, and 23,1947 , and the full committee considered it on July 23 and 25, reporting it favorably to the House of Representatives on July 25, 1947 (H.R. REP. No. 1093, 80th Cong., Ist Sess. (1947)). The Senate Foreign Relations Committee met in executive session on July 8 and 12, reporting favorably to the Senate in Senate Reports 522 and 559 on July 14 and 15, 1947. The bill passed the Senate on July 17, 1947; then passed the House as amended on July 26, 1947, and on the same day the Senate agreed to the house amendnients. See House Comm. on Foreign Affairs, supra note 79 , at 316 n.1.

130. S. REP. No. 559, 80th Cong., 1st Sess. 7 (1947). See generally Senate Foreign Relations Comm., July 12, supra note 79 (repeatedly expressed concern over the security threat presented by free access).

131. H.R. REP. No. 1093, 80th Cong., 1st Sess. (1947).

132. Id.; see also Memorandum by Albert F. Bender, Jr. of the Mission at the United Nations (July 1, 1952), [1952-54] 3 Foreign REL. UNiTED STATES 214, 216 [hereinafter Bender Memorandum]. The United States still maintains this position. Secretary of State Shultz recently claimed that the United States had the right to deny entry into the United States of any individual PLO member directly implicated in terrorist acts. 133 CoNG. REC. E1636 (daily ed. April 29, 1987) (letter from Secretary of State Shultz to Representative Kemp). Because the Headquarters Agreement unconditionally grants invitees a right of entry independent of contrary U.S. laws, Headquarters Agreement, supra note 5, art. IV, $\S 13(\mathrm{a})$, the only source from which a U.S. right to deny entry could derive would be the section 6 security reservation. The U.S. also referred to this position as the grounds for its denial of a visa to Yasir Arafat to address the General Assembly. See Statement Denying Visa for Arafat, N.Y. Times, Nov. 27, 1988, $\S 1$ at 5, col. 1 (official State Department statement that "[t]he Congress of the United States conditioned the entry of the U.S. into the U.N. headquarters agreement on the retention by the U.S. Government of the authority to bar the entry of aliens associated with or invited by the United Nations 'in order to safeguard its own security" "). In addition, Abraham Sofaer, the Legal Adviser to the State Department, stated that the right to establish missions was conditioned on U.S. national interests. N.Y. Times, Jan. 13, 1988, at 3 , col. 1 . 
Despite the domestic legislative history, a more natural readimg of the language of the reservation would be that the second clause himits the first, resulting in a surrender of U.S. control over entry into and residence in the immediate vicinity of the headquarters district. And nothing in the record shows that the Umited States gave notice of the resolution's legislative history to either the Secretary-General or the United Nations. ${ }^{133}$ Therefore, it is unlikely that the United Nations must accept an exercise of U.S. control over entry into the headquarters district and its immediate vicimity.

Under the terms of the Headquarters Agreements only arbitration could resolve this conflict, ${ }^{134}$ and the State Department has doubted that an arbiter would be sympathetic to the U.S. position. ${ }^{135}$ Not surprisingly, the United States has been hesitant to rely on the section 6 reservation to curtail entry and residence rights granted in sections 11 and 13 . A recent attempt to deny entry to PLO Chairman Yasir Arafat based on the section 6 reservation produced world-wide condemnation. ${ }^{136}$ Thus, although the Umited States maintains that rights of entry and residence are limited by U.S. security concerns, it may have difficulty enforcmg these limnts. The United Nations disputes the U.S. interpretation of its security rights, and arbitration would probably not produce a result favorable to the United States.

In suin, the residence rights granted under the Headquarters Agreement were strictly limited. Only temporary residence rights were contemplated, and these were conditioned on nonabuse of privilege, and were limited to the immediate vicinity of the headquarters district. In addition, the limited role that the Umited States envisioned for NGO involvement at the United Nations would have precluded any permanent relationship between NGO's and the General Assembly. Poor drafting of the section 6 security reservation frustrated Congress' attempt to further condition these rights upon the interests of U.S. security.

Thus, the contemporaneous interpretations of the Headquarters Agreeinent indicate that the United States had no obligation whatsoever

133. Bender Memorandum, supra note 132, at 217. As the Legal Adviser to the State Department has noted, "[u]nder international law, statements made during internal ratification proceedings (and not formally communicated to a treaty partner prior to ratification) cannot alter the obligations which that party actually assumed under the treaty negotiated." Sofaer, Treaty Interpretations: A Comment, 137 U. PA. L. REV. 1437, 1438 (1989). See also VCLT, supra note 17, art. 46.

134. The United States and the United Nations are bound to have their differences under the Agreement arbitrated by a tribunal of three arbitrators. Headquarters Agreement, supra note 5, art. VIII, § 21(a).

135. Bender Memorandum, supra note 132, at 218.

136. Only the U.S. and Israel voted against a resolution rebuking the United States for its refusal to grant a visa to Yasir Arafat to address the General Assembly. See U.N. Votes to Move Session to Geneva, N.Y. Times, Dec. 3, 1988, at A1, col. 1. 
to accord permanent observer NGO's a privilege of permanent residence. The following Part traces the sparse public record of U.S. practice with respect to permanent observers to determine if custom could have resulted in a modification of the Headquarters Agreement or in the creation of an independent "special custom" obligation.

\section{IV}

The Rise of the Permanent Observer: Custom AND ACQUIESCENCE AS SOURCES OF A RIGHT TO RESIDENCE

The extension of permanent invitations to observe all sessions of the General Assembly has no basis in treaty. Neither the Headquarters Agreement nor the U.N. Charter make any provision for them. Instead, the institution of permanent observers developed entirely from practice. Permanent observer invitations were extended first to nonmember States, then to organizations of States, and finally to national liberation inovements. Eventually, both the United States and the United Nations began to consider permanent observers as section $11(5)$ invitees, with all respective rights and privileges.

While the United States took no action to prevent the establishment of permanent observer missions, neither did it demonstrate any sense of legal obhigation to permit the inissions. Thus, the United States probably has no custom-based obligations to permanent observers.

\section{A. The Creation of Permanent Observer Missions}

Permanent observers established permanent inissions and took up year-round residence in the United States even before they had any clear legal status. The first permanent observers were representatives of nonmember States that solicited the Secretary-General for permission to appoint observers. Switzerland formally appointed a permanent observer to the United Nations in 1948, and other States quickly followed. ${ }^{137}$ In 1949, the U.N. Secretary-General wrote that he encouraged the appointment of observers of nonmember States, and attempted to supply thein with all necessary facilities, even though their legal status was unclear. ${ }^{138}$

In 1948, the General Assembly voted officially for the first time to extend an invitation to observe the sessions of the General Assembly. The honor went not to a nonmeniber State, but to the Organization of American States (OAS), a regional organization of States. ${ }^{139}$ Represent-

137. R. JAY, UNITED NATIONS OBSERVER StATUS 11 (1976) [hereinafter ObSERVER StatUs]. Austria, Italy and Korea followed in 1949. Id.

138. Permanent Missions to the United Nations: Report of the Secretary-General, 4 U.N. GAOR C.6 Annex (Agenda Item 50) at 17, U.N. Doc. A/939/Rev.1 and Rev.1/Add.1 (1949).

139. 1948-49 U.N.Y.B. 974, U.N. Sales No. 1950 I.11. 
atives of Czechoslovakia, Poland, Yugoslavia, and the Union of Soviet Socialist Republics disputed the validity of the invitation. They argued that it was contrary to the provisions of the U.N. Cliarter, which made no allowance for the Secretary-General to extend permanent invitations to organizations not connected with the Umited Nations. ${ }^{140} \mathrm{Mr}$. Bogoniolov, speaking for the USSR, commented that "the status of observer had not been provided for in the Charter, nor had any decision been taken by the General Assembly to that effect." 141

The ineniber States eventually conipromised by agreeing to interpret the invitation as setting a precedent for the invitation of other regional organizations of States, which allayed concerns that States who were inenibers of the OAS would benefit froin dual representation. ${ }^{142}$ The General Assenibly extended similar invitations to the League of Arab States, the Organization of African Unity, the European Economic Community, the Council for Mutual Economic Assistance, and the Islamic Conference. ${ }^{143}$

United Nations documents contain very few references to permanent observers after these early invitations were extended. ${ }^{144}$ In 1962 , the Office of Legal Affairs of the Umited Nations issued a meniorandun1 to the Acting Secretary-General agani conceding the lack of legal basis for permanent observers. ${ }^{145}$ The menioranduni, which only discussed permanent observers froin nonmeinber States, denionstrated the limited obligation of both the United Nations and the United States to permanent observers:

Legal Basis for the institution of Permanent Observers

2. There are no specific provisions relating to Permanent Observers of non-menber States in the United Nations Charter, in the Headquarters Agreement with the United States Governinent or in General Assembly resolution 257(III) of 3 Decenber 1948 relating to Permanent Missions of Member States. The Secretary-General referred to Permanent Observers of non-nembers in his report to the fourth session of the Assembly on Permanent Missions (A/939), but no specific action was taken by the Assembly either at that time or later to provide an express legal basis for the institution of Permanent Observers. It therefore rests purely on practice as so far followed. ...

Facilities accorded to Permanent Observers

3. Since Permanent Observers of non-nieniber States do not have an officially recognized status, facilities which are provided then by the Secretariat are strictly confined to those which relate to their attendance

140. Id. at 975 .

141. 3(1) U.N. GAOR (151st plen. mtg.) at 362 (1948) (statement of Mr. Bogomolov).

142. 1948-49 U.N.Y.B. 975, U.N. Sales No. 1950 I.11.

143. OBSERVER Status, supra note 137 , at 12.

144. I have been unable to find any other references to permanent observers before 1962 .

145. U.N. JURID. Y.B. 236-37, U.N. Doc. ST/LEG/8 (prov. ed. 1962). 
at public meetings and are generally of the same nature as those extended to distinguisled visitors at United Nations Headquarters. . . .

4. No otlier formal recognition or protocol assistance is extended to Permanent Observers by the Secretariat. Thus no special steps are taken to facilitate tlie granting of United States visas to thein and their personnel, nor for facilitating the establislıment of their offices in New York. ...

Permanent Observers and the question of privileges and immunities

5. Permanent Observers are not entitled to diplomatic privileges or iminumities under the Headquarters Agreement or under otlier statutory provisions of the liost State. . . . If they are not listed in the United States diplomatic list, whatever facilities they may be given in the United States are nierely gestures of courtesy by the United States authorities. ${ }^{146}$

Congressional opponents of the PLO observer mission cited to this memo to show that the United States had no obligation to provide residence rights to permanent observers, because the memo both denies that observers have an "officially recognized status," and states that they are not entitled to diplomatic privileges and immunities. ${ }^{147}$ But the men1orandunı is arguably ambiguous. First, the statement that permanent observers lack official status could be read to mean that they have no official status that distinguishes then fron other section 11(5) invitees. The practice of inviting observing delegations as section 11(5) invitees supports such an interpretation. ${ }^{148}$ It would make little sense if the perinanent nature of their invitations stripped observers of the limited residence rights afforded invitees. The meinorandum states that there are no specific provisions relating to permanent observers, which may iniply that there are general provisions-such as those relating to invitees-that apply.

Second, the statement that permanent observers are not entitled to diplomatic privileges and immuinties need not imply that they do not have limited residence rights. Technically, the right to residence is a privilege or an immunity because it is an exemption from the operation of U.S. laws, but it is probably not a traditional diplomatic privilege. In the traditional diplomatic context, host States have the power to refuse to accept a diplomat, to terminate the special diplomatic status of a diplonuat, or effectively to close a diplomatic mission by terminating diplonnatic relations at will. ${ }^{149}$ A diplomat traditionally has no right of

146. Id.

147. See, e.g., 133 CoNG. REC. \$13,852 (daily ed. Oct. 8, 1987) (statement of Mr. Grassley); 133 ConG. REC. S18,191 (daily ed. Dec. 16, 1987) (statement of Mr. Helms).

148. See, e.g., Memorandum by the Legal Adviser (Fisher), supra note 101, at 68 (representatives of NGO's subject to admission under section 11(5)); see also 133 CoNG. REC. E1636 (daily ed. Apr. 29, 1987) (letter from Secretary of State Shultz that PLO permanent observer mission is present in the United States as "invitees" under the Headquarters Agreement).

149. See Vienna Convention on Diplomatic Relations, Apr. 18, 1961, 23 U.S.T. 3227, T.I.A.S. No. 7502, 500 U.N.T.S. 95, arts. 9, 45. 
permanent residence. Thus, claiming that a permanent observer is not entitled to diplomatic privileges does not deny the observer a right of permanent residence. Accordingly, the memorandum is not inconsistent with a view that permanent observers are section 11(5) invitees entitled to a privilege of residence.

The issue of permanent observers does not come up again in the public record until 1973.150 That year, Secretary of State Rogers was asked at a press conference in Paris whether the United States had "objections to, or would ... place obstacles in the way of, opening up an observer office of the Provisional Revolutionary Government [of Vietnain] at the Uinited Nations." Mr. Rogers rephed that "[it] is a inatter for the United Nations to decide," but also expressed his personal view that "based on past precedent, there would be no justification for coming to that conclusion."151 Read inost expansively, Mr. Roger's statement inphies that the United States recognized a legal obhgation to afford permanent residence to permanent observer nonmeinber States. The statement, however, could as easily miply that the Umited States had no political objections to the establishment of a Vietnamese observer mission. Thus, this statement, as well as the records of the United Nations up to the time this statement was inade, is unclear about the residence rights of permanent observers.

\section{B. The Extension of Permanent Observer Invitations to Nongovernmental Organizations}

On November 22, 1974, the Uinited Nations extended a standing invitation to the PLO to attend sessions of the General Assembly and all international conferences sponsored by the General Assembly or the specialized agencies as a permanent observer. ${ }^{152}$ This invitation marked the first time that observer status had been conferred on an organization that was neither a State nor a regional organization of States. It was eventually followed by a permanent observer invitation to the South West Africa People's Organization (SWAPO). ${ }^{153}$ Although the United Nations has not extended any other permanent observer invitations to NGO's, it has adopted a practice of inviting delegations from all national liberation inovements recognized by the Organization of African Unity and the League of Arab States to observe particular conferences or meetings. ${ }^{154}$

150. I have been unable to find further discussion in the public record of the rights of permanent observers until 1973.

151. 1973 Dig. U.S. PRAC. INT'L L. 34.

152. G.A. Res. 3237, 29 U.N. GAOR Supp. (No. 31) at 4, U.N. Doc. A/9631 (1974).

153. 1976 DIG. U.S. PRAC. INT'L L. 44. The U.S. abstained in part because it feared that the recognition of SWAPO would bar the recognition of other legitimate voices of Namibia. Id.

154. OBSERVER STATUS, supra note 137, at 17. Many national liberation movements have 
U.N. member States fiercely debated the PLO invitation. ${ }^{155}$ Many Western countries, includimg the Umited States, felt that such an invitation conferred State status on a national liberation movement and therefore was wholly imappropriate. ${ }^{156}$ The United States voted against the mvitation and abstained on the subsequent extension of permanent observer status to SWAPO. ${ }^{157}$

The following year, delegates to the United Nations' Conference on the Representation of States in their Relations with International Organizations ${ }^{158}$ atteinpted to expand the privileges and immumities of NGO permanent observers and cement their right to establish permanent missions. The conference's purpose was to review the draft articles of the International Law Commission in order to draft a convention addressing, inter alia, the status of nonmember State (as opposed to NGO) observer missions. ${ }^{159}$ The resulting convention, Vienna Convention on the Representation of States in their Relations With International Organizations of a Uinversal Character (CRSIO), exphicitly provided permanent observer States the right to open and maintain observer missions in the lost country. ${ }^{160}$ This right was to be respected regardless of the state of relations between the host country and the permanent observer State and was not dependent on host country consent. ${ }^{161}$ In addition, the CRSIO called for full diplomatic privileges and immunities for meinbers of observing State missions, including mimumity from arrest, detention, and criminal jurisdiction for members of the State's observer mission and their families; ${ }^{162}$ inviolability from entry or search of the mission, the transportation vehicle of the mission, and the homes of members of the mission and their families; ${ }^{163}$ and the right of unrestricted travel in the United States. ${ }^{164}$

Because international law regarding international organizations had developed ouly since the creation of the League of Nations, the CRSIO

taken advantage of this offer, including the People's Movenent for the Liberation of Angola, the Moveinent for the National Liberation of Coinoro, and the Seychelles' People's United Party. Id. at 13.

155. 29 U.N. GAOR (2296th plen. mtg.) at 1059, U.N. Doc. A/PV.2296 (1974).

156. Id. at 1071 (statements of Mr. Richard of the United Kingdoin and Sir McIntyre of Australia).

157. Id. at 1066 .

158. U.N. Conference on the Representation of States In Their Relations With International Organizations, Vienna 1975, 1 \& 2 Official Records, Summary Records, U.N. Doc. AVCONF.67/18 (1975).

159. L. DEMBINSKI, supra note 92, at 11.

160. Vienna Convention on the Representation of States in their Relations with International Organizations of a Universal Character, art. 5(2), U.N. Doc. A/CONF.67/16 (1975) [hereinafter CRSIO].

161. Id. art. $82(1)$.

162. Id. arts. $28,30,36$, and 37 .

163. Id. arts. $23,29,36$, and 37 .

164. Id. art. 26. 
did not purport to codify existing rules of customary international law, but rather to formulate new rules by drawing on and supplementing existing practice. ${ }^{165}$ The conference was poorly attended, however, and the resulting convention imposed such unbalanced obligations on States that host international organizations that two thirds of the attendees declined to adopt it. ${ }^{166}$

At the conclusion of the CRSIO conference, a number of States attempted to solidify the position of national hiberation movements as observers on equal footing with observing States. ${ }^{167}$ Although the Conference was convened only to examine the draft articles of the International Law Commission, on March 11, 1975 tliese States submitted a hasty resolution to be annexed to the Final Act of the CRSIO and called for an immediate vote. ${ }^{168}$ This resolution requested the 1975 General Asseinbly to examine the question of ensuring effective participation of national liberation movements as observers to the Uinted Nations, and to determine their status, facilities, privileges, and immunities. ${ }^{169}$ It also recominended that, until the General Assembly could resolve the issue, all States concerned should grant such observers the facilities, privileges, and immumities essential to their functions as outlined in the CRSIO. ${ }^{170}$ The resolution passed two days later, 53 to 5 with 15 abstentions. ${ }^{171}$ However, due to lack of time, the issue was not addressed by the General Assembly until $1980 .{ }^{172}$

In 1980, the Sixth (Legal) Committee recominended that the General Asseinbly pass a resolution calling for States to ratify the CRSIO and to accord national hiberation movements the facilities, privileges and imınunities outlined in it. ${ }^{173}$ The vote on the text of the resolution in the Sixth (Legal) Coinmittee was 70 to 10 with 29 abstentions (United States votmg against). ${ }^{174}$ Dissenting States objected to the resolution because they believed, inter alia, that because national liberation inovements were not States they should not be treated as such, and that

165. L. DemBINKS1, supra note 92 , at 10.

166. Id. at $10-12$.

167. U.N. Doc. A/CONF.67/L.1 and Add.1 (1975), reprinted in U.N. Conference on the Representation of States In Their Relations With International Organizations, Vienna 1976, 2 Official Records, Suunnary Records, at 193, U.N. Doc. A/CONF.67/18/Add.1 (1976) [hereinafter UNITED NATIONS 2].

168. U.N. Conference on the Representation of States In Their Relation With International Organizations, Vienna 1976, 1 Official Records, Summary Records, at 64, U.N. Doc. A/Conf.67/18 (1976) [hereinafter UNITED NATIONS 1].

169. UNITED Nations 2, supra note 167, at 195.

170. Id.

171. UNited Nations 1 , supra note 168 , at 64.

172. See 1979 U.N.Y.B. 1159-60, U.N. Sales No. E.82 I.1 (consideration of the issue was postponed).

173. 1980 U.N.Y.B. 1154-55, U.N. Sales No. E.83 I.1.

174. Id. at 1155 . 
the extension of facilities, privileges, and immunities to national liberation movements required far more extensive discussion. ${ }^{175}$ Nevertheless, the General Assembly adopted the text as Resolution 35/167 on December 15,1980 , by a vote of 97 to 10 with 29 abstentions (United States voting against). ${ }^{176}$ Substantially identical General Assembly resolutions were again passed on December 16, 1982 by a vote of 110 to 10 with 17 abstentions (United States voting against) ${ }^{177}$ and on December 13, 1984 by a vote of 106 to 10 with 21 abstentions (United States voting against). ${ }^{178}$ Despite the passage of these resolutions, the United States has consistently declined to extend to permanent observers any privileges and immunities beyond those of the ordinary invitee under section $11(5) .{ }^{179}$

\section{The Lack of a Custom-Based Obligation to Afford Residence Rights to Permanent Observers}

During the debates over the Anti-Terrorisin Act, the State Departinent contended that the United States was legally obligated under the Headquarters Agreement to keep the PLO observer mission open. Because the Headquarters Agreement did not contemplate a right of permanent residence for NGO observers, any U.S. obligation to perinanent observers must be based in custom. This could be either a new special custom obligation, or a custom-based treaty modification. ${ }^{180}$ Even assuming the validity of international law doctrines of custombased bilateral obligation, however, the meager record of U.S. practice makes an argument of custom-based obligation difficult.

The record does contain some evidence of the first element of custom-based obligation-consistent State practice. For over forty years, the United States had never publicly objected to the establishment of permanent observer missions froin nonmember States. The United States acquiesced to the establishment of NGO permanent observer missions for sixteen years. The United States also permitted permanent observers to remaim in the United States year-round.

But the second element-expression of a heightened sense of legal obligation-appears to be missing before the debate on the Anti-Terrorism Act. Whether sufficient opinio juris was displayed is at best

175. Id.

176. Id.

177. 1982 U.N.Y.B. 1392, U.N. Sales No. E.85 I.1.

178. 1984 U.N.Y.B. 1104, U.N. Sales No. E.87 I.1.

179. In addition to privileges of transit and residence, the United Nations has expressed the opinion that observers enjoy immunity from legal process with respect to words spoken or written and all acts performed by members of the delegation in their official capacities before relevant United Nations organs. See 1979 U.N. JURID. Y.B. 169-70.

180. See supra notes $18-35$ and accompanying text. 
debatable. U.S. acquiescence could easily be explained as the unwillingness to pay the political price of shutting down an observer mission.

Thus, before the passage of the ATA, it appears that the United States had no obligation from either treaty or custon to provide permanent residence rights to NGO permanent observers. It is not surprising, then, that Congress did not express an intent to violate niternational law when it drafted the ATA. ${ }^{181}$ The unilateral executive statenients that provided the basis for the new international obhigation were not made until Congress discussed the Act.

\section{$\mathrm{V}$ \\ THe AtTempted Closure of THe PLO OBSERVer \\ MisSion: UNILATERAL STATEMENTS OF U.S. \\ OFFICIALS AS A SOURCE OF \\ OBLIGATION}

On October 7, 1985, terrorists armed with automatic weapons boarded the cruise ship Achille Lauro, seized the ship "on behalf of" the PLO, and separated the Americans from the other tourists as targets for special attention. ${ }^{182}$ The following afternoon, the terrorists executed an elderly wheelchair-bound American man, Leon Klinghoffer, and duniped both his body and wheelchair overboard. ${ }^{183}$ The incident was one of niany in which PLO terrorists dehiberately or incidentally targeted Americans for attack. It helped set the stage for a confrontation over the extent of U.S. obligations to unwanted permanent observer missions. ${ }^{184}$

\section{A. The Passage of the Anti-Terrorism Act}

In October 1986, the Senate Judiciary Committee sent a telegrain to the President, asking him to explore means for closing the PLO offices im the United States. ${ }^{185}$ Representative Kemp ${ }^{186}$ and Senator Dole ${ }^{187}$ also sent letters to Secretary of State George Slultz urging the administration to consider closing the PLO offices. In response, both received form letters:

181. See infra notes $222-23$ and accompanying text.

182. Stille, The PLO: A Suit Provides an Inside Look, Nat'l L.J., Dec. 28, 1987, at 1, col. 1.

183. Id.

184. See 133 CoNG. REc. S6447 (daily ed. May 14, 1987) (statement of Senator Grassley); 133 CoNG. REc. S6448-49 (daily ed. May 14, 1987) (statement of Senator Dole); 133 CoNG. REc. H4048 (daily ed. May 28, 1987) (statement of Senator Dornan).

185. 133 CONG. REC. $S 6449$ (daily ed. May 14, 1987) (telegram from Senate Judiciary Committee to President).

186. 133 Cong. REc. E1635 (daily ed. April 29, 1987) (letter from Representative Kemp to Secretary of State George Shultz).

187. 133 CoNG. REC. S6449 (daily ed. May 14, 1987) (telegram from Senate Judiciary Committee to President). 
The PLO observer mission in New York was established as a consequence of General Assembly Resolution 3237(XXIX) of November 22, 1974, which invited the PLO to participate as an observer in the sessions and work of the General Assembly. . . . The U.S. has made clear that PLO observer mission personnel are present in the United States solely in their capacity as "invitees" of the United Nations within the meaning of the Headquarters Agreement. While we therefore are under an obligation to permit PLO observer mission personnel to enter and remain in the Umited States to carry out their official functions at UN headquarters, we retain the right to deny entry to, or expel, any individual PLO representative directly implicated in terrorist acts. ${ }^{188}$

Unsatisfied, Representative Kemp pressed the issue. Even conceding the U.S. obhigations to imvitees, he argued, '[s] houldn't our 'invitation' [to the PLO] be limited to specific meetings, perhaps even for the entire duration of the General Assembly, rather than entertaining a year round PLO presence in Manhattan?'189

In May, Senator Grassley introduced the Anti-Terrorisin Act of 1987 which provided in pertiment part:

It shall be unlawful ... not withstanding any provision of the law to the contrary, to estabhish or maimtain an office, headquarters, premises or other facilities or establishments within the jurisdiction of the United States at the behest or direction of, or with funds provided by the Palestine Liberation Organization or any of its constituent groups, any successor to any of those, or any agents thereof. ${ }^{190}$

In the same month, Representative Herger introduced companion legislation in the House of Representatives. ${ }^{191}$ The Senate passed the ATA as Senate Amendment No. 940 to the Foreign Relations Authorization Act. ${ }^{192}$ One openly discussed purpose of the ATA was to force closure of the PLO observer mission im New York. ${ }^{193}$ Proponents of the ATA argued that the United States had no obhigation under the Headquarters Agreement to permit the PLO permanent observer mission to maintain offices in New York. ${ }^{194}$

188. 133 Cong. Rec. E1636 (daily ed. Apr. 29, 1987) (letter from Secretary of State George Shultz to Representative Kemp); 133 CoNG. Rec. S6,449 (daily ed. May 14, 1987) (letter from Secretary of State George Shultz to Senator Dole).

189. 133 CoNG. REC. E1636 (daily ed. April 29, 1987) (letter from Representative Kemp to Secretary of State Shultz). The General Assembly meets for approximately three months of the year. See supra note 93.

190. S. 1203, 100th Cong., 1st Sess., 133 Cong. REc. S6448 (daily ed. May 14, 1987).

191. 133 CONG. REC. H4047 (daily ed. May 28, 1987).

192. 133 CONG. REC. $\$ 13,851, \mathrm{~S} 13,855$ (daily ed. Oct. 8, 1987).

193. 133 CoNG. REC. S6448 (daily ed. May 14, 1987) (statement of Senator Dole).

194. 133 CONG. REC. S16,605 (daily ed. Nov. 20, 1987) (statement of Senator Grassley). Senator Helms stated that closing the mission would be "entirely within our Nation's obligations under international law." 133 CoNG. REC. S18,190 (daily ed. Dec. 16, 1987). Representative Burton stated that observer missions have "no-zero-rights in the headquarters agreement." 133 CoNG. ReC. H11,425 (daily ed. Dec. 15, 1987). 
The response of the United Nations to the introduction of the ATA was swift and direct. On October 13, 1987, the U.N. Secretary-General learned of the progress of the legislation and expressed his concern to the U.S. Representative. ${ }^{195}$ When the U.N. General Assenibly Committee on Relations with the Host Country discussed the n1atter, the U.S. Representative stated that closure of the PLO nission would be inconsistent with the duties of the United States under the Headquarters Agreement. He cautioned, however, that it was then still too early to speculate on the outconie of the legislative process. ${ }^{196}$ The Host Country Committee reported the matter to the Sixth (Legal) Committee of the General Assembly, which in turn reported to the plenary assembly. ${ }^{197}$

On December 17, 1987, the General Assenibly adopted Resolution $42 / 210 B$. The resolution requested the United States "to abide by its treaty obligations under the [Headquarters Agreement]," and asked "the Secretary-General to take effective measures to ensure full respect for [the Headquarters Agreement]." 198 Nevertheless, the President signed the Foreign Relations Authorization Act, including the amendment containing the ATA, mto law five days later. ${ }^{199}$ The ATA was to go nito effect on March 21, 1988. ${ }^{200}$ When the United States refused to give the Secretary-General requested assurances that the ATA would not be applied so as to curtail or affect the existing arrangenients for the PLO mission, the Secretary-General atteinpted to nivoke the Headquarters Agreeinent arbitration clause. ${ }^{201}$ The United States declined, lowever, to submit to arbitration. ${ }^{202}$

On Marcl 11, the U.S. Representative informed the SecretaryGeneral that the U.S. Attorney General had determined that he was required to close the PLO observer mission "irrespective of any obliga-

195. Documents Concerning the Controversy Surrounding the Closing of the Palestine Liberation Organization Observer Mission to the United Nations 27 INT'L LEGAL MATERIALS 712 (1988).

196. Id.

197. Id.

198. The General Assembly added that it would continue to keep the matter under active review. Id. at 713. General Assembly resolution $42 / 210 \mathrm{~B}$ was adopted by a vote of $145-0-1$ (Israel voting against, the United States not participating). Id. at 712 .

199. Id. at 712 .

200. Id.

201. Id. at 713 .

202. Id. When the United States refused to arbitrate, the General Assembly called upon the United States (by further nearly unanimous resolutions) to abide by its treaty obligations and requested an advisory opinion from the International Court of Justice on the U.S. duty to arbitrate. Id. On April 26, the International Court of Justice rendered its Advisory Opinion holding unanimously that the United States was obligated to arbitrate under the Headquarters Agreement. Id. at 714. The General Assembly reiterated its call on March 23 by adopting General Assembly resolution $42 / 230$ by a vote of 148 to 2 (no abstentions, the United States and Israel voting against). Id. at 713. On May 13, the General Assembly approved the Advisory Opinion by adopting General Assembly resolution $42 / 232$ by a vote of 136 to 2 (no abstentions, the United States and Israel voting against). Id. 
tion the United States may have" under the Headquarters Agreement. ${ }^{203}$ On March 22, 1988, the Justice Department apphied for a court order to close the PLO permanent observer mission. ${ }^{204}$

In public, tlie State Departnient unequivocally and vocally opposed the ATA. On July 31, 1987, Secretary of State George Sliultz wrote to Senators Dole, Grassley, and Pell and Representative Kenip that closure of the observer mission "would be seen as a violation of a U.S. treaty obligation."205 On Noveniber 25, 1987, before the General Assembly, the U.S. Representative to the United Nations reiterated Secretary of State Sliultz' belief that 'tlie closing of the mission would constitute a violation of United States obligation under the Headquarters Agreement."206 On Deceniber 23, State Departnient spokesperson Phyllis Oakley told the press that the ATA "if miplemented, would be contrary to our international legal obhigations under the Headquarters Agreemient."207 In January 1988 Abraham Sofaer, Legal Adviser to the State Departnient, stated that "[i]t is our judgment that the Headquarters Agreement as interpreted and applied would be violated" by the closures. ${ }^{208}$ Other news articles reported that Sofaer called the bill "unlawful"209 and that Shultz called it one of the "dumber" things Congress had done. $^{210}$

While the State Departnent took this position publicly, some of its analysts doubted the legal validity of its position. An internal State Department document reported by the press in Noveniber 1987 stated that the PLO had no legal riglit to operate an office in New York, but that it would be impractical to sliut it down. ${ }^{211}$ The report noted that the Headquarters Agreenient did not specifically deal with permanent observers, and that the United States had never acknowledged an international legal obligation to accord privileges and immunities to observer missions. The report stated that the institution of permanent observer "rests purely on practice." 212

As a matter of principle, the U.S. government, as host country, can argue

203. Id. at 713 .

204. Id. at 714 .

205. United States v. Palestine Liberation Org., 695 F. Supp. 1456, 1467 n.24 (S.D.N.Y. 1988).

206. U.N. Doc A/C.6/42/SR.58 para. 3 (Nov. 25, 1987) quoted in United States v. Palestine

Liberation Org., 695 F. Supp. at 1467.

207. United States v. Palestine Liberation Org., 695 F. Supp. at 1467 (citing Department of

State Daily Press Briefing at 8 (Dec. 23, 1987)).

208. N.Y. Times, Jan. 13, 1988, at A3, col. 1.

209. Commentary: U.S. Must Fulfill Its Obligations as Host to U.N., Xinhua General Overseas News Service, Feb. 11, 1988.

210. Clash Over PLO Mission in N.Y.: Whose Law Has the Right of Way?, Nat'l L.J., May 16, 1988, at col. 3 .

211. Schweid, State Department Calls Shutting Down PLO Office Impractical, A.P., Nov. 4, 1987, reprinted in 133 CONG. REC. S18,190 (daily ed. Dec. 16, 1987).

212. Id. 
that it should not be obligated to accord observer missions privileges and immumities that it has not expressly agreed to provide.... In hight of the practice of both the United Nations and the U.S. government it is not practical for the U.S. government to take such a position at this time. ${ }^{213}$

The report concluded that "[a]s a practical matter it is too late to challenge the institution of permanent observer missions or the extension of that institution to non-governmental organizations like the PLO."214

The confusion over the extent of U.S. legal obligations to permanent observers is not surprising. Until the passage of the ATA, there was little support in the public record for a claim of obligation to extend permanent residence to permanent observers. The executive statements of legal obligation, however, probably provided the missing support.

Under the primciples set forth by the ICJ in the Greenland ${ }^{215}$ and Nuclear Tests ${ }^{216}$ cases, unilateral statements of obligation can be considered a source of obligation in themselves. ${ }^{217}$ Accordingly, the United Nations inay rely on the statements made by executive brancli officials of high government rank who acted within their capacity as representatives of the U.S. governinent. Just as the ICJ found an international obligation when the Damish foreign minister made representations to the government of Norway in the Greenland case, an arbiter is likely to find that the statements made to the United Nations by the U.S. Representative that closure of the PLO mission would violate U.S. treaty obligations are in themselves binding. Just as the ICJ found that statements niade to the press by the French government were binding in the Nuclear Tests case, an arbiter is likely to find that the statements made by executive brancli officials to the press create binding obligations. Therefore, to the extent that ICJ judgments represent international law, the United States was bound by the unilateral statements of obligation.

The executive statements also add credibility to an argnnent of custom-based obligation. The executive statements evidence a sense of legal obligation that had previously been lacking. When the statements are combined with the history of U.S. acquiescence in practice, they supply the eleinents for a special custom obhigation. Alternately, the statements could evidence intent to modify the treaty, providing support for an argument that subsequent agreement of the parties modified the Headquarters Agreenient.

In essence, then, the executive statements that claimed an existing legal obligation created a new legal obligation. They provided sufficient

\footnotetext{
213. Id.

214. Id.

215. Legal Status of Eastern Greenland (Den. v. Nor.), 1933 P.C.I.J. (ser. A/B) 53.

216. Nuclear Tests (Austl. v. Fr.), 1974 I.C.J. 253.

217. See supra notes $36-40$ and accompanying text.
} 
evidence of intent to be bound to satisfy theories of both express and implied consent.

\section{B. United States v. Palestine Liberation Organization}

Proinpt judicial repudiation of the executive statenents concerning the ATA imight have prevented the expansion of U.S. international obligations to permanent observers. But relying principally on the State Department affirmations of the U.S. obligations, the court in United States v. Palestine Liberation Organization refused to issue a court order closing the PLO observer mission. ${ }^{218}$ On August 29, 1988, the Department of Justice decided that "on balance, the interests of the United States are best served by not appealing."219 The Justice Department identified the U.S. role as host to the United Nations as a factor in the decision. $^{220}$

The court in United States v. Palestine Liberation Organization found that the Umited States had an international legal obligation under the Headquarters Agreement to permit U.N. imvitees to maintain permanent offices. ${ }^{221}$ The court then found that the provisions of the ATA requiring the closure of the PLO permanent observer inission were mconsistent with U.S. obhgations under the Headquarters Agreement. "It has been [a] maxim of statutory construction since the decision in Murray v. The Charming Betsy that 'an act of Congress ought never to be construed to violate the law of nations, if any other possible construction remaims." "222 Because the ATA showed no clear congressional intent to overrule the Headquarters Agreement, the portion of the AntiTerrorism Act that required the closure of the New York PLO mission was not given effect. ${ }^{223}$

218. 695 F. Supp. 1456 (S.D.N.Y. 1988).

219. U.S. Drops Effort to Oust PLO's U.N. Mission in N.Y., L.A. Times, Aug. 30, 1988, at 1, col. 1.

220. Id.

221. Urited States v. Palestine Liberation Org., 695 F. Supp. at 1465-69, 1471. The court began the opinion by describing the history of the PLO as a United Nations observer, as well as the history of the ATA. Id. at 1458-61. The court assumed personal jurisdiction over the PLO because of its continuous presence in New York City. Id. at 1461. The court had subject matter jurisdiction despite an arbitration clause in the Headquarters Agreement because the issue before the court was the enforcernent of the ATA, not the resolution of a dispute between the United States and the United Nations. Id. at 1461-64.

222. Id. at 1465 (quoting Weinberger v. Rossi, 456 U.S. 25, 32 (1982) (citations omitted)).

223. Id. at $1465,1469-71$. The court's finding that Congress did not intend to override international law was not entirely without support, despite the statutory language requiring closure "notwithstanding any provision of the law to the contrary." S. 1203, 100th Cong., 1st Sess., 133 CoNG. Rec. S6448 (daily ed. May 14, 1987). At least some members of Congress were aware that, in the absence of more explicit language, the provision requiring closure of the PLO observer mission might not be given effect if in fact the United States had contrary international legal obligations. See 133 CoNG. REC. S18,185 (daily ed. Dec. 16, 1987) (statement of Senator Pell). 
The court's discovery that the Headquarters Agreement grants permanent observers the right to establisl1 permanent missions is surprising and deserves careful scrutiny. The court first cited the provision of section 11 of the Headquarters Agreement that conferred the right of transit on invitees, and wrote that "[ $t]$ hese rights could not be effectively exercised witlout the use of offices."224 Implicitly locating the riglit to permanent offices in section 11, the court then found that sucl a right was not contradicted by section 13 .

It is particularly significant that Section 13 limits the application of United States law not only with respect to the entry of aliens, but also their residence. The Headquarters Agreement thus contemplates a continuity limited to official United Nations functions and is entirely consistent with the maintenance of missions to the United Nations. The exemptions of Section 13 are not limited to members, but extend to invitees as well. ${ }^{225}$

The court did not address the failure of the Headquarters Agreement to provide for permanent missions, or describe any of the treaty limitations on residence riglits, but instead implied an organization's right to establish a permanent mission from an mvitee's limited riglit of residence. Significantly, the court assuined witliout discussion that organizations rather than individuals are proper invitees under the Headquarters Agreement. ${ }^{226}$ The court also assuined witlout discussion that those invited to observe the General Assembly have official functions at the United Nations even when the General Asseinbly is not in session.

The court turned its attention to U.S. practice, citing forty years of U.S. acquiescence to the presence of observer missions in New York. ${ }^{227}$ The court failed to distinguish between the accommodation of permanent observers from nonmember States or of permanent observers from regional State organizations, and the accommodation of NGO permanent observers. Instead, the court lumped all invitees together.

The court then attempted to find the second element of a custoinbased obligation, a U.S. sense of legal obligation.

After the United Nations invited the PLO to participate as a permanent observer, the Department of State took the position that it was required to provide access to the U.N. for the PLO. The State Department at no time disputed the notion that the rights of entry, access and residence guaranteed to invitees include the riglit to maintain offices. ${ }^{228}$

These sentences are misleading. The State Department did not adopt a

224. United States v. Palestine Liberation Org., 695 F. Supp. at 1465-66.

225. Id. at 1466 .

226. It is understandable that the court did not examine this assumption; the United Nations had invited the PLO, not individual members of the PLO.

227. Id.

228. Id. 
new stance regarding residence rights after the PLO invitation. The State Department has always acknowledged a general obligation to provide access to the United Nations for invitees on official business consistent with U.S. security interests. But the court's statement assumes that a right of access includes a right of permanent residence. While invitees enjoy guaranteed rights of entry, access, and limited residence, the issue of whether invitees have a right to reside permanently in the Umited States-or to inamtain permanent offices-is one of the very issues that the court should have resolved.

The State Departinent's failure to "dispute the notion" that a right of residence includes the right to inaintain offices is also not evidence of a right to permanent offices. If a right to inaintam offices is inherent in the right of residence, it cannot be broader than that right. A right of temporary residence could give rise only to a right of temporary offices. Before the dispute over the ATA arose, there was no indication that anyone had ever inaintained that permanent observers had a right of permanent residence, inuch less that such a right existed for NGO's and included permanent offices.

Furthermore, the quoted passage seeins to imply that the right to inaintain offices is an individual right concomitant with the rights of entry and temporary residence guaranteed to individual imvitees or representatives under the Headquarters Agreement. But, in fact, the court ultimately held that observing organizations have a right to establish and maintain permanent missions.

The court then rehed on a finding in an earlier case, AntiDefamation League of B'nai B'rith $v$. Kissinger, ${ }^{229}$ to support its view that the PLO had a right to permanent offices. ${ }^{230}$ "The view that under the Headquarters Agreement the Umited States must allow PLO representatives access to and presence in the vicimity of the United Nations was adopted by the court in Anti-Defamation League of B'nai B'rith $v$. Kissinger."231

That case, however, lends no support whatsoever for finding that the PLO had a right to establish a permanent mission. Instead, the AntiDefamation League court upheld a right of entry for a PLO delegation invited to observe a specific General Assembly session before the PLO received permanent observer status. ${ }^{232}$ The Anti-Defamation League had sought a court order requiring the executive to show cause why the PLO delegation should not be denied entry, or in the alternative, to show

229. Civil Action No. 74 C1545 (E.D.N.Y. 1974), partially reprinted in 1974 Dig. U.S. PRAC. INT'L L. 27 [hereinafter Anti-Defamation League].

230. Id.

231. United States v. Palestine Liberation Org., 695 F. Supp. 1456, 1466 (S.D.N.Y. 1988).

232. Anti-Defamation League, supra note 229, at 27. 
why the delegation's activities should not be strictly limited. ${ }^{233}$ The court declined to issue the order, and dismissed the case without prejudice. The court conditioned its dismissal on the issuance of restricted visas to the delegation that would limit the delegation's travel to within a twenty-five-mile radius of Columbus Circle. ${ }^{234}$ The court then recommended that further restrictions on the delegation be considered. ${ }^{235}$ Neither residence rights nor the right to maintaim offices were at issue in that case. The Headquarters Agreement does provide for temporary U.S. residence in the immediate vicinity of the headquarters district for invitees on official business. The Anti-Defamation League court did not find an epheineral right of the PLO delegation to be permanently present in the vicinity of the Umited Nations.

Concluding its discussion of past U.S. practice as evidence of legal obligation, the United States v. Palestine Liberation Organization court cited U.S. acquiescence to the presence of the PLO observer mission: "The United States has, for fourteen years, acted in a manner consistent with a recognition of the PLO's rights in the Headquarters Agreenient. This course of conduct under the Headquarters Agreement is iniportant evidence of its meaning."236 Again, this statement begs the question. It assunies the existence of permanent residence rights as "the PLO's rights in the Headquarters Agreement," a treaty that never contemplated the estabhishment of permanent missions of menber States, much less the establishment of permanent missions of observing national hiberation movenients. Nor can it be reasonably asserted that a fourteen-year-old practice, begun more than twenty-five years after the Headquarters Agreenient was concluded, is evidence of the orignial imtent of the parties.

Finally, the court turned to executive statements made during the deliberations on the ATA. As discussed previously, these statenients unainbiguously acknowledged an obhigation to permit permanent observers to establish permanent missions in the United States under the Headquarters Agreement, and they probably provide a basis for obligation under international law. The court, however, abandoned its effort to interpret the Headquarters Agreenent under international legal rules of treaty interpretation, and instead deferred to the official interpretation of the executive agency charged with enforcing the treaty. The court stated:

Although not conclusive, the ineaning attributed to treaty provisions by the Government agencies charged with their negotiation and enforce-

233. Id.

234. Id.

235. Id.

236. United States v. Palestine Liberation Org., 695 F. Supp. 1456, 1466 (S.D.N.Y. 1988). 
ment is entitled to great weight. The interpretive statements of the United Nations also carry some weight, especially because they are in harmony with the interpretation given to the Headquarters Agreement by the Departnent of State. Thus, the language, application and interpretation of the Headquarters Agreenent lead us to the conclusion that it requires the United States to refrain from interference with the PLO Observer Mission in the discharge of its functions at the United Nations. ${ }^{237}$

So saying, the court concluded its finding of international legal obligation, holding that the United States is obligated to refrain from interfering with the functioning of the PLO observer mission ${ }^{238}$ and cannot close it down without violating U.S. treaty obligations. ${ }^{239}$

VI

\section{REFLECTIONS ON THE AFTERMATH}

The United States is now, for all practical purposes, obligated to allow permanent observers to establish permanent missions. Undoubtedly, both international arbiters and world opinion would concur with this finding. But both the substance of the new obligation and the process by which it was created are worrisome.

\section{A. The New Obligation: Unnecessary and Unwise}

As outlined in the United States v. Palestine Liberation Organization opinion, the scope of the new U.S. obligation under the Headquarters Agreenient is very broad. The court held that the Uinted States has an obligation to "refrain from impairing the functions of the PLO Observer Mission," 240 and that permanent observer orgainzations have a right to nraintaim permanent missions.

The court declared this new privilege of residence for invitees based, at least in part, on the court's own understanding of what is necessary for mvitees to "function." The court did not limit the applicability of the right to establish a mission to permanent observers, or to particular types of legal entities. If invited by the United Nations, a State, an NGO, or even conceivably an individual or corporation could claim permanent residence rights.

Because the United Nations has an unqualified right to extend invitations under section 11(5), the United States has no way to protect its own interests and security by refusing to allow a permanent observer to establish a permanent presence. The United States could try to invoke

237. Id. at 1467 (citations omitted).

238. Id. at 1468 .

239. Id. at $1464-65,1471$.

240. Id. at 1471 . 
the section 6 security reservation, but any section 6-based right to deny entry to an individual invitee rests on dubious ground and is unlikely to be affirmed by an arbiter. ${ }^{241}$ The end result is that the United Nations is the sole legal judge of who is allowed entry into and residence in the immediate vicinity of the United Nations.

The United Nations has a longstanding practice of inviting "national liberation novenrents" recognized by the Organization of African Unity and the League of Arab States to participate as ad hoc observers. ${ }^{242}$ The hist of observers has included a variety of national hiberation niovenients, such as the People's Movement for the Liberation of Angola, the Movelnent for the National Liberation of Comoro, and the Seychelles' People's United Party. ${ }^{243}$ It is entirely possible that nore national liberation nrovements will receive permanent observer invitations in the future.

The United States has thus far resisted the United Nations' repeated demands that observing national liberation novenients receive privileges and immunities equal in scope to those accorded to State missions accredited to the United States. ${ }^{244}$ But the grant of the right to establish a permanent mission to an invitee niay be the start of an uncontrolled expansion of invitee rights. The grant further blurred the line between U.N. nienibers and nonmenibers, and between States and NGO's. Furthermore, the pressures that allowed the creation of this new privilege still exist. Just as pohtical expediency led to the creation of the right to establish a mission for all permanent observers, political expediency niay lead to de facto or de jure extensions of diploniatic immunity from criminal process.

No expansion of privileges and immunities should be undertaken without careful consideration. Recent years have shown an alarming number of abuses of existing diploniatic privileges and immunities, ranging fron parking violations to nuurder. ${ }^{245}$ Such abuses include the 1981

241. Reisman, An International Farce: The Sad Case of the PLO Mission, 14 YALE J. INT'L L. 412 (1989); see supra notes 133-36 and accompanying text.

242. See, eg., G.A. Res. 3102, 28 U.N. GAOR Supp. (No. 30) at 141, U.N. Doc. A/9030 (1973) (urging that national liberation movements rccognized by regional intergovernmental organizations be invited to a conference on human riglits in armed conflicts); G.A. Res. 3118, 28 U.N. GAOR Supp. (No. 30) at 102, U.N. Doc. A/9030 (1973) (recognizing statements of representatives of national liberation movements concerning independence of colounal countries); E.S.C. Res. 1835, 56 U.N. ESCOR Supp. (No. 1) at 1, U.N. Doc. E/5544 (1974) (requesting that representatives of liberation movements recognized by the Organization of African Uinity or the League of Arab States be invited to a conference on population); E.S.C. Res. 1840, 56 U.N. ESCOR Supp. (No. 1) at 3, U.N. Doc. E/5544 (1974) (requesting that representatives of recognized national liberation movements be invited to the World Food Conference).

243. OBSERVER STATUS, supra note 137, at 13; 1975 U.N.Y.B. 880, U.N. Sales No. E.77.I.1.

244. See supra notes $167-78$ and aecompanying text.

245. See First Report of the Foreign Affairs Committee of the House of Commons, 34 INT'L \& CoMP. L.Q. 610 (1985) (British Foreign Afrairs Committee's rccommendations in response to the 
case of Manuel Ayree, son of a Ghanaian representative to the United Nations, who was identified by New York victims as an armed rapist but was immune from arrest or prosecution; ${ }^{246}$ the attempted kidnapping of ex-Minister Dikko by drugging him and attempting to ship him out of England in a diplomatic pouch; $;{ }^{247}$ and the murder of Constable Fletcher by shots fired from imside the Libyan Embassy in England. ${ }^{248}$ Expanding the number of people entitled to privileges and immumities can have serious consequences.

The extension of diplomatic privileges and immunities to permanent observers presents particular problems. No U.S. consent is required for the United Nations to extend permanent observer status. Nor does the definition of permanent observer stay constant. The class of potential permanent observers has expanded from nonmember States to regional State organizations to national liberation movements. One commentator in the 1970s speculated that the day was not far off before multinational corporations would also be included as permanent observers. ${ }^{249}$

The extension of privileges and immumities to NGO invitees presents additional concerns. NGO's, like private nidividuals, have only limited legal personality under international law. ${ }^{250}$ Consequently, NGO's would benefit from imternationally imposed obligations on the United States without legally owing any reciprocal duties to the United States, such as a duty to respect U.S. laws. Traditional diplomatic benefits, suclı as reciprocity, and traditional diplomatic pressures, such as trade embargoes, would be ineffective to ensure compliance.

Furthermore, because of their lack of internal organization, NGO liberation movements have been unable to guarantee the behavior of their members. This problem was clearly illustrated when the Klinghoffer family attenipted to sue the PLO for the murder of Leon Klinghoffer. Although a member of the Executive Committee of the PLO admitted planning and ordering the attack, the PLO denied that it could be held responsible for his acts because of its lack of cohesion. ${ }^{251}$

The closure of the PLO mission would have been politically unwise. The executive may have been justifiably concerned that the ATA, cor-

abuse of diplomatic immunities and privileges). See generally C. Ashman, Diplomatic Crime (1987); C. Ashman \& P. Trescott, Outrage (1986).

246. See C.AshmAN \& P. TRESCOTT, supra note 245, at 22-53 (1987).

247. First Report of the Foreign Affairs Committee of the House of Commons, supra note 245, at 610,614 .

248. Id. at 610 .

249. OBSERVER STATUS, supra note 137 , at 37 .

250. Because NGO's are not created by treaties, they do not have international legal personality through delegation by States. See M. JANIS, supra note 8, at 140-43. In contrast, international organizations whose members are States have international legal personality through delegation of sovereign power. Id.

251. Stille, supra note 77 , at 1 , col. 1 . 
rectly perceived by the PLO as a direct attack, ${ }^{252}$ would jeopardize delicate Middle-East peace negotiations. ${ }^{253}$ With the exception of Israel, the entire U.N. community opposed the closing. Rightly or wrongly, such a closing would have seriously undermined American geopohitical prestige, and created or reinforced feelings that the Urited States was incapable of acting as a suitable host for the United Nations. The closure would also have resulted in a direct conflict with the United Nations itself. Under the Headquarters Agreenient, such a conflict would require arbitration. ${ }^{254}$ The executive inay have been concerned about submitting the issue to arbitration because of the difficulty of finding a mutually acceptable arbitrator who would be unswayed by the veheinent world opposition to the ATA.

The executive, however, would have been better advised to concede a custom-based obligation to permit the existence of the PLO and SWAPO missions on the grounds of past acquiescence. A custoni-based obligation presumably could be limited to the PLO and SWAPO alone. By claiming instead that the obligation arose froin the Headquarters Agreennent, the executive extended the obligation to all U.N. invitees. The executive inay have hoped to control the resultant security threat by use of the dubious American niterpretation of the section 6 security reservation. But U.S. efforts to invoke the resolution to refuse a visa to Yasir Arafat brought world-wide condemnation. ${ }^{255}$ The General Assembly deplored the U.S. decision, claiming that it constituted a violation of U.S. obligations under the Headquarters Agreennent. ${ }^{256}$ When the United States refused to back down, the Uinted Nations reconvened in Geneva. ${ }^{257}$ Thus, the U.S. section 6 security reservation may be very thin armor indeed.

\section{B. Executive and Judicial Expansionism}

This Comment has discussed how the judicial and executive responses to the ATA have soine disturbing inplications for the scope of U.S. obligations under the Headquarters Agreement. Perhaps the most disturbing aspect of those responses, however, is the implications they have for the constitutional role of the executive (and the courts) in the treaty-making process. The Headquarters Agreement was a treaty concluded by the President pursuant to express authorization from

252. U.N. Secretary Proclaims Lawful Status of PLO Missions, Xinhua Gen. Overseas News Service, Oct. 21, 1987.

253. U.S. Will Not Fight Decision on PLO Mission, U.P.I., August 30, 1988; State Dept. Aides Pressing Meese to Delay Closing P.L.O. Mission, N.Y. Times, Feb. 5, 1988, at 1, col. 2.

254. Headquarters Agreement, supra note 5, art. VII, § 21.

255. N.Y. Times, Dec. 1, 1988, at 6, col. 1.

256. $I d$.

257. N.Y. Times, Sept. 26, 1989, at 15, col. 1. 
Congress. ${ }^{258}$ Once ratified, a treaty becomes the supreme law of the land along with the Constitution and federal laws. ${ }^{259}$

It is the duty of the President to execute the laws of the United States. ${ }^{260}$ Of necessity, every time the executive branch applies a law to a new situation, it gives new meaning to the words of the law. In that sense, it is the duty of the executive to interpret treaties just as it is the executive's duty to interpret any other federal law. ${ }^{261}$ The executive should not, however, interpret the Headquarters Agreement treaty contrary to the clear intent of Congress.

In the instant case, the executive's unilateral actions created an international obligation to provide permanent residence rights for a permanent observer. By creating this new obligation, the executive contravened congressional intent regarding the Headquarters Agreement, and in so doing may also have violated the Constitution. The executive expanded the U.S. obligations under the Headquarters Agreement without authority from Congress. It appears, moreover, that the executive created the new obligation after and in response to federal legislative efforts. This executive action, combined with the action of the court in United States v. Palestine Liberation Organization, has created a powerful new tool to overrule federal laws, $m$ addition to the veto provided in article I of the Constitution. ${ }^{262}$ The court overruled contrary provisions of the ATA because the Act stated no intent to violate any international obligations, but the executive created the new international obligation during the passage of the ATA. Thus, the court helped the executive exercise what was, in effect, a veto of the closure provision of the ATA.

Although Congress is free to pass another law requiring the closure of permanent observer missions, the court in United States v. Palestine Liberation Organization made clear that it would require an explicit recitation of intent to violate international law before upholding a closure provision. ${ }^{263}$ It may be more difficult to pass legislation that states an intention to violate international law than it would be to override a presi-

258. Joint Resolution, supra note 5. For the U.S. Attorney General's opinion on the binding effect of an international agreement made pursuant to a joint resolution of Congress, see International Agreement Executed by the President, 40 Op. Att'y Gen. no. 111 (1946), reprinted in 15 DEP'T ST. BuLL. 1068 (Dec. 1946). Other treaties have also been concluded pursuant to a joint resolution of Congress. See Paper Prepared in the Office of Special Political Affairs, Justification for Submitting General Convention in Form of Joint Resolution [1947] 1 FOREIGN REL. U.S. 38 (postal conventions and membership in the International Labor Organization).

259. U.S. CONST. art. VI, § 3.

260. U.S. CoNST. art. II, §3.

261. Rostow, The Reinterpretation Debate and Constitutional Law, 137 U. PA. L. REV. 1451, 1455 (1989).

262. Article I, $\S 7(2)$ of the U.S. Constitution provides that the President may veto a bill, which then must gather a two-thirds majority in Congress to pass.

263. 695 F. Supp. 1456, 1465 (S.D.N.Y. 1988). 
dential veto. And to exercise this new unconstitutional veto power, the executive need only make enough contrary unilateral statements to bind the United States internationally while a bill is in the process of becoming a law.

The executive could make a colorable argument that it created no new obligations in the instant case, but legitimately interpreted a treaty obligation in the face of unforeseen developinents. Because of the potential for abuse, lowever, executive power to interpret treaty terms contrary to evidence of congressional intent must be precisely defined. Calling a new obligation an "interpretation" does not make it one.

The extent to which the executive can legitimately reinterpret a treaty term is currently the subject of great debate in the context of arms treaties. ${ }^{264}$ In several instances, the executive lias interpreted the terms of arms treaties so as to limit U.S. obligations contrary to the expressed will of at least soine senators. ${ }^{265}$ The executive's actions in those cases are less troubling than in the instant case because in this case the executive created a new or broader international obligation than Congress origmally intended. A more restrictive understanding of U.S. obligation can always be suppleinented by a further agreenent, since presumably the otlier parties will be willing to agree to an interpretation that expands the United States' obligations. The expansion of an existing international obligation, lowever, lias different foreign policy implications because the otlier parties may refuse to accept a more limited interpretation. The executive sliould liave been required to slow an affirmative grant of permission froin Congress before it expanded the Headquarters Agreement. ${ }^{266}$

The extension of permanent resident riglits seems to be inconsistent

264. See Biden, Jr., \& Ritch III, The Treaty Power: Upholding a Constitutional Partnership, 137 U. PA. L. REV. 1529 (1989); Block, Casey \& Rivkin, Jr., The Senate's Pie-in-the-Sky Treaty Interpretation: Power and the Quest for Legislative Supremacy, 137 U. PA. L. REV. 1481 (1989); Fisher, Congressional Participation in the Treaty Process, 137 U. PA. L. REV. 1511 (1989); Koplow, Constitutional Bait and Switch: Executive Reinterpretation of Arms Control Treaties, 137 U. PA. L. REV. 1353 (1989); Nunn, A Common-Sense Definition of "Common Understanding," 137 U. PA. L. REV. 1523 (1989); Rostow, supra note 261; Sofaer, supra note 133; Trimble, The Constitutional Common Law of Treaty Interpretation: A Reply to the Formalists, 137 U. PA. L. REv. 1461 (1989).

265. See, e.g., Koplow, supra note 264, at 1359-60 (executive branch desire for a narrower interpretation of U.S. obligations under the Geneva Protocol on Chemical and Bacteriological Warfare); $i d$. at 1366-70 (executive branch desire for a narrower interpretation of U.S. limitations under the ABM Treaty). Koplow recognizes that the adoption of an affirmative obligation has different implications because of notions of State sovereignty. Id. at 1424.

266. As Secretary of State Dean Acheson recognized in 1950, the executive branch of Government has no authority by administrative action or interpretation to increase the scope, or otherwise alter the meaning, of the provisions of the Headquarters Agreement beyond their purport, as approved by the Congress of the United States. The Secretary of State to the Ambassador in Denmark (Anderson), supra note 100, at 57, 59-60 (discussing whether unforeseen circumstances would justify the expansion of the list of persons entitled to transit rights to include the families of representatives of the press). 
with Congress' intent and outside the bounds of legitimate executive imterpretation. When Congress approved the signing of the Headquarters Agreement, it did not intend either to grant permanent residence rights to U.N.-affiliated individuals or to permit the establishment of permanent missions. Residence rights and their implications for national security were of great importance to Congress and were thoroughly debated. ${ }^{267}$ Furthermore, the joint resolution of Congress authorizing the Headquarters Agreement expressly provided that the President was authorized only to bring the Headquarters Agreement into effect "with such changes therein not contrary to the general tenor thereof and not imposing any additional obligations on the United States."268

Professor Trimble has argned that reliance solely on the original intent of the Senate is too static a model for determining congressional intent regarding treaty interpretation. Congressional acquiescence to an executive interpretation sliould also be considered as indicative of intent. $^{269}$ Under this theory, one could argue that Congress demonstrated an intent coinpatible witl an executive grant of the right to establish a permanent mission because Congress failed to challenge the permanent residence of permanent observers. But in the absence of any executive statement of obligation in the public record before the passage of the ATA there seems to be no executive interpretation to which Congress could acquiesce.

The executive in the instant case sinply overreached when it created new obligations under the Headquarters Agreement. Unless Congress is willing to state intent to violate international law, or unless the judiciary is willing to police the Executive, this powerful new executive veto will reinain in place. If the reasoning of United States $v$. Palestine Liberation Organization is followed, no judicial help will be forthcoming.

The United States v. Palestine Liberation Organization decision reflects a new judicial activism in interpreting U.S. international legal obligations. The court may have increased the burden on Congress to show intent to violate international law by requiring an explicit statement of intent. ${ }^{270}$ This, coupled witl unduly weighty deference to the executive's most recent interpretation of treaty obligations, effectively guts the power of Congress to mandate a particular treaty interpretation by statute. The removal of this key tool leaves intact few congressional safe-

267. See, e.g, House Comm. on Foreign Affairs, supra note 79, at 249-52, 256-57, 263, 265, 268; Senate Foreign Relations Comm., July 8, supra note 77, at 30-41.

268. Joint Resolution, supra note 5 (emphasis added). The Chairman of the Senate Foreign Relations Committee called this clause "the most important language, from my point of view." Senate Foreign Relations Comm., July 8 , supra note 77 , at 7.

269. Trimble, supra note 264 , at $1461,1467$.

270. See Reisman, supra note 241 , at 429,431 . 
guards against executive overreaching in the interpretation of treaties. ${ }^{271}$

The United States v. Palestine Liberation Organization court justified its finding of a U.S. obligation to allow permanent offices in part on the ground that transit rights could not be effectively exercised otherwise. ${ }^{272}$ Thus, the court created a privilege of residence for U.N. invitees based on its own view of what invitees need in order to function. This action may lead other courts to determine for themselves what privileges and immunities these invitees require. The determmation appears to be without reference to the Headquarters Agreement itself, its preparatory works, its historical context, or even a careful scrutiny of practice under the treaty.

The decision in United States v. Palestine Liberation Organization ignored both the constitutional balance between the President and Congress in the treaty making process, and the proper role of the courts in giving meaning to treaty terms. Thus, the decision sets an ominous precedent for a new constitutional balance between the three branches of government with respect to international relations.

\section{CONCLUSION}

The grant of the right to establish a permanent mission to U.N. permanent observers that occurred mcident to the passage of the ATA was an unwarranted case of executive overreaching. It created a broad, undesirable obligation for the United States. Moreover, the executive's creation of contrary international obligations while legislation is pending threatens the balance of power between the executive and Congress. The United States should act quickly to control resultant damage.

Congress should act to define and limit the newly created residence obligation. A specific disavowal of further obligations to permanent observers, or a statement defining and limiting those obligations, would go far to prevent the contmued erosion of the rights of the United States under the Headquarters Agreement. The International Organizations Imnunities Act of $1945,{ }^{273}$ which provides for the extension of privileges and imnrunities to selected international organizations, as well as for the revocation of those privileges and immunities, is an example of the kind of legislation that is required. By specifically retaining the right to revoke such privileges, the United States would clearly indicate that its extension of courtesies does not imply a desire to be bound to extend courtesies under international law. The right of residence should be lint-

271. See Rostow, supra note 261, at 1455; Block, Casey \& Rivkin, Jr., supra note 264, at 150709.

272. See supra note 224 and accompanying text.

273. 22 U.S.C. § 288 (1988). 
ited to current permanent observers on the basis of prior acquiescence to their presence.

The courts should act to limit the impact of United States $v$. Palestine Liberation Organization. The argument that effective exercise of transit rights requires permanent residence should be rejected because it inisinterprets the terms of the Headquarters Agreement. The rule of the case should be limited to granting the right of permanent residence to the PLO permanent observer mission. Language im the opinion that seems to indicate that all U.N. invitees would enjoy a right of permanent residence, and perhaps other privileges that the courts find to be necessary to the "function" of invitees, should be dismissed as dicta.

Fimally, the courts must be more sensitive to the constitutional balance between the President and Congress in the treaty-making process, which is threatened by the ability of the executive to create international legal obhigations through umilateral statements without the participation of Congress. The courts and the executive should be sensitive to the legal ramifications of such statements in international tribunals. 